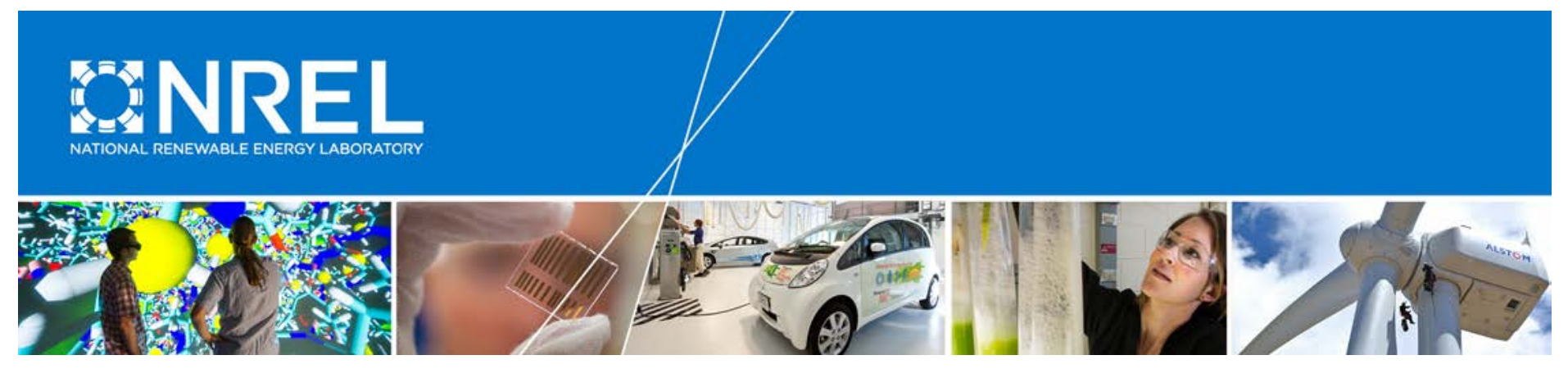

\title{
Installed Cost Benchmarks and Deployment Barriers for Residential Solar Photovoltaics with Energy Storage: Q1 2016
}

Kristen Ardani, ${ }^{1}$ Eric O'Shaughnessy, ${ }^{1}$ Ran Fu, ${ }^{1}$ Chris McClurg, ${ }^{2}$ Joshua Huneycutt, ${ }^{3}$ and Robert Margolis ${ }^{1}$

${ }^{1}$ National Renewable Energy Laboratory

${ }^{2}$ Rocky Mountain Institute

${ }^{3}$ U.S. Department of Energy

NREL is a national laboratory of the U.S. Department of Energy Office of Energy Efficiency \& Renewable Energy Operated by the Alliance for Sustainable Energy, LLC

This report is available at no cost from the National Renewable Energy Laboratory (NREL) at www.nrel.gov/publications.

Technical Report

NREL/TP-7A40-67474

February 2017

Contract No. DE-AC36-08G028308 


\section{Installed Cost Benchmarks and Deployment Barriers for Residential Solar Photovoltaics with Energy Storage: Q1 2016}

Kristen Ardani, ${ }^{1}$ Eric O'Shaughnessy, ${ }^{1}$ Ran Fu, ${ }^{1}$ Chris McClurg, ${ }^{2}$ Joshua Huneycutt, ${ }^{3}$ and Robert Margolis ${ }^{1}$

${ }^{1}$ National Renewable Energy Laboratory

${ }^{2}$ Rocky Mountain Institute

${ }^{3}$ U.S. Department of Energy

Prepared under Task No. ST6B1452

NREL is a national laboratory of the U.S. Department of Energy Office of Energy Efficiency \& Renewable Energy Operated by the Alliance for Sustainable Energy, LLC

This report is available at no cost from the National Renewable Energy Laboratory (NREL) at www.nrel.gov/publications.

National Renewable Energy Laboratory 15013 Denver West Parkway Golden, CO 80401

303-275-3000 • www.nrel.gov
Technical Report

NREL/TP-7A40-67474

February 2017

Contract No. DE-AC36-08GO28308 


\section{NOTICE}

This report was prepared as an account of work sponsored by an agency of the United States government. Neither the United States government nor any agency thereof, nor any of their employees, makes any warranty, express or implied, or assumes any legal liability or responsibility for the accuracy, completeness, or usefulness of any information, apparatus, product, or process disclosed, or represents that its use would not infringe privately owned rights. Reference herein to any specific commercial product, process, or service by trade name, trademark, manufacturer, or otherwise does not necessarily constitute or imply its endorsement, recommendation, or favoring by the United States government or any agency thereof. The views and opinions of authors expressed herein do not necessarily state or reflect those of the United States government or any agency thereof.

This report is available at no cost from the National Renewable Energy Laboratory (NREL) at www.nrel.gov/publications.

Available electronically at SciTech Connect http:/www.osti.gov/scitech

Available for a processing fee to U.S. Department of Energy and its contractors, in paper, from:

U.S. Department of Energy

Office of Scientific and Technical Information

P.O. Box 62

Oak Ridge, TN 37831-0062

OSTI http://www.osti.gov

Phone: 865.576.8401

Fax: 865.576.5728

Email: reports@osti.gov

Available for sale to the public, in paper, from:

U.S. Department of Commerce

National Technical Information Service

5301 Shawnee Road

Alexandria, VA 22312

NTIS http://www.ntis.gov

Phone: 800.553 .6847 or 703.605 .6000

Fax: 703.605.6900

Email: orders@ntis.gov 


\section{Acknowledgments}

The authors would like to thank the following individuals and organizations for their contributions to and review of this work: Kate Anderson (National Renewable Energy Laboratory), Pete Bronski (Panasonic), Tripp Hyde (Hyde Engineering), Stefan Kratz (Cleanbridge Technologies), Lars Lisell (National Renewable Energy Laboratory on detail at City University of New York), Ravi Manghani (GreenTech Media Research), Joyce Mclaren (National Renewable Energy Laboratory), Jesse Morris (Rocky Mountain Institute), Brandon Provalenko (Outback Power), Otto VanGeet (National Renewable Energy Laboratory), and Brian Warshay (SolarCity). We also thank Don Gwinner and Jarett Zuboy for editing and graphics support. Finally, we gratefully acknowledge funding for this work from the Solar Energy Technologies Office of the U.S. Department of Energy's Office of Energy Efficiency and Renewable Energy under contract number DE-AC36-08GO28308. 


\section{List of Acronyms}

$\mathrm{AC}$

AHJ

ASP

BLS

BNEF

BOS

CEC

CPUC

CUNY

DC

DOE

EPC

FERC

FICA

GTM

IOU

IRS

ITC

$\mathrm{kW}$

kWh

LCOE

MW

NEM

NGOM

NREL

OTCR

PII

PV

RMI

SGIP alternating current

authority having jurisdiction

average selling price

U.S. Bureau of Labor Statistics

Bloomberg New Energy Finance

balance of system

California Energy Commission

California Public Utilities Commission

City University of New York

direct current

U.S. Department of Energy

engineering, procurement, and construction

Federal Energy Regulatory Commission

Federal Insurance Contributions Act

GreenTech Media

investor-owned utility

Internal Revenue Service

investment tax credit

kilowatt

kilowatt-hour

levelized cost of energy

megawatt

net energy metering

net-generation output meter

National Renewable Energy Laboratory

Office of Technical Certification and Research

permitting, inspection, and interconnection

photovoltaic(s)

Rocky Mountain Institute

Self-Generation Incentive Program 


\section{Executive Summary}

Behind-the-meter energy storage products have the potential to optimize the value of rooftop solar photovoltaic (PV) systems while increasing the flexibility of electricity consumers and enhancing grid operations. However, significant cost and value barriers continue to hinder the large-scale deployment of PV-plus-storage systems. In this report, we fill a gap in the existing literature by providing detailed component- and system-level installed cost benchmarks for residential PV-plus-storage systems. We also examine other barriers to increased deployment of PV-plus-storage systems in the residential sector. The results are meant to help technology manufacturers, installers, and other stakeholders identify cost-reduction opportunities and inform decision makers about regulatory, policy, and market characteristics that impede PV-plus-storage deployment. This report is the first in what we expect to be a series of PV-plus-storage benchmark reports that will document progress in cost reductions for this emerging market segment over time.

To analyze component costs and system prices for PV-plus-storage installed in the first quarter of 2016, we adapt the National Renewable Energy Laboratory's (NREL's) component- and system-level bottom-up cost-modeling approach for standalone PV. Our methodology includes accounting for all component and project-development costs incurred when installing residential systems, and it models the cash purchase price for such systems excluding the investment tax credit. Costs are represented from the perspective of the installer; thus, all hardware benchmarks represent the price at which components are purchased by the installer. Importantly, we also apply a $17 \%$ fixed margin to all direct costs to model the sustainable sales price paid by the end user to the installer. This $17 \%$ fixed margin is referred to as "net profit" and is added to total installed costs as a separate category. We do not include any additional price gross-up or adders, which are common in the marketplace today. We use this approach owing to the wide variation in installer profits ${ }^{1}$ in the residential sector, where end-user pricing is highly dependent on region and project specifics such as local retail electricity rate structures, local rebate and incentive structures, competitive environment, and overall project or deal structures. In addition to our original analysis, model development, and review of the published literature, we derive inputs for our model and validate our results via interviews with industry and subject-matter experts.

One challenge to analyzing component costs and system prices for PV-plus-storage installations is choosing an appropriate metric. Unlike standalone PV, energy storage lacks standard widely accepted benchmarking metrics, such as dollars-per-watt $(\$ / W)$ of installed capacity and levelized cost of energy (LCOE). We explain the difficulty of arriving at a standard approach for reporting storage costs and prices; we then provide a rationale for using the total installed price of a standard PV-plus-storage system as our primary metric, rather than using a metric normalized to system size.

We present results for two grid-tied system applications, which we refer to as the "small-battery case" and "large-battery case," in addition to several typical system configurations. The smallbattery case - which uses a 5.6-kW PV array and a 3-kW/6-kWh lithium-ion battery system-is designed to provide back-up power for a limited number of critical loads in the event of a grid outage and enable a typical customer to optimize self-consumption of PV electricity (including

\footnotetext{
${ }^{1}$ Profit is one of the differentiators between "cost" (aggregated expenses incurred by an installer to build a system) and "price" (what the end user pays for a system).
} 
peak-demand shaving and time-of-use shifting). ${ }^{2}$ Figure ES-1 shows our benchmarking results for this application, including new direct-current (DC)- and alternating-current (AC)-coupled systems (when PV and storage are installed simultaneously) and AC-coupled systems with the storage system retrofitted after the PV array. ${ }^{3}$ The benchmarked price of such a system is about twice as high as the price of a standalone 5.6-kW PV system. The DC-coupled system price $(\$ 27,703)$ is $\$ 1,865$ lower than the AC-coupled system price $(\$ 29,568)$ for a new PV-plusstorage installation. The price premium for AC-coupled systems is mainly due to higher hardware, labor, and sales and marketing costs associated with the additional grid-tied inverter and more complex system design and engineering requirements. However, installed price is not the only consideration when comparing AC- and DC-coupled systems: AC-coupled systems are more efficient in applications where PV energy is generally used at the time of generation, and DC-coupled systems are more efficient in applications where PV energy is stored and used later. The installed price is $\$ 32,786$ for an AC-coupled system when the battery is retrofitted to an existing PV array, which is $\$ 3,218$ higher than the price of installing the PV and storage simultaneously. ${ }^{4}$ The simultaneous installation results in savings related to installation labor and electrical wiring as well as indirect costs (supply chain costs, overhead, regulatory costs, and profit).

\footnotetext{
${ }^{2}$ Generally, as net metering rates decline, the economics of using residential PV-plus-storage systems for selfconsumption improves. Although currently only a small number of residential demand charges and time-of-use tariffs exists, as states move away from full retail-rate net metering (e.g., Hawaii, Nevada) and as utilities implement residential time-of-use pricing (e.g., California, Illinois), we anticipate that the economics of PV-plus-storage for self-consumption will become increasingly competitive.

${ }^{3}$ NREL's modeled DC-coupled system includes a single, bi-directional inverter shared between the PV array and the battery. The bi-directional inverter is also assumed to be dual function (i.e., can operate in on-grid and off-grid modes). In our AC-coupled system, to charge a battery, PV power is first converted (DC to AC) through a grid-tied inverter and then converted (AC to DC) through a second, battery-based inverter. Similar to our modeled DCcoupled system, the battery-based inverter is assumed to be bi-directional and dual function.

${ }^{4}$ We do not model the costs of adding a DC-coupled battery to an existing PV system, because this configuration is not commonly deployed owing to required inverter and associated wiring replacement and potential for violation of ownership agreements terms for third-party-owned systems.
} 


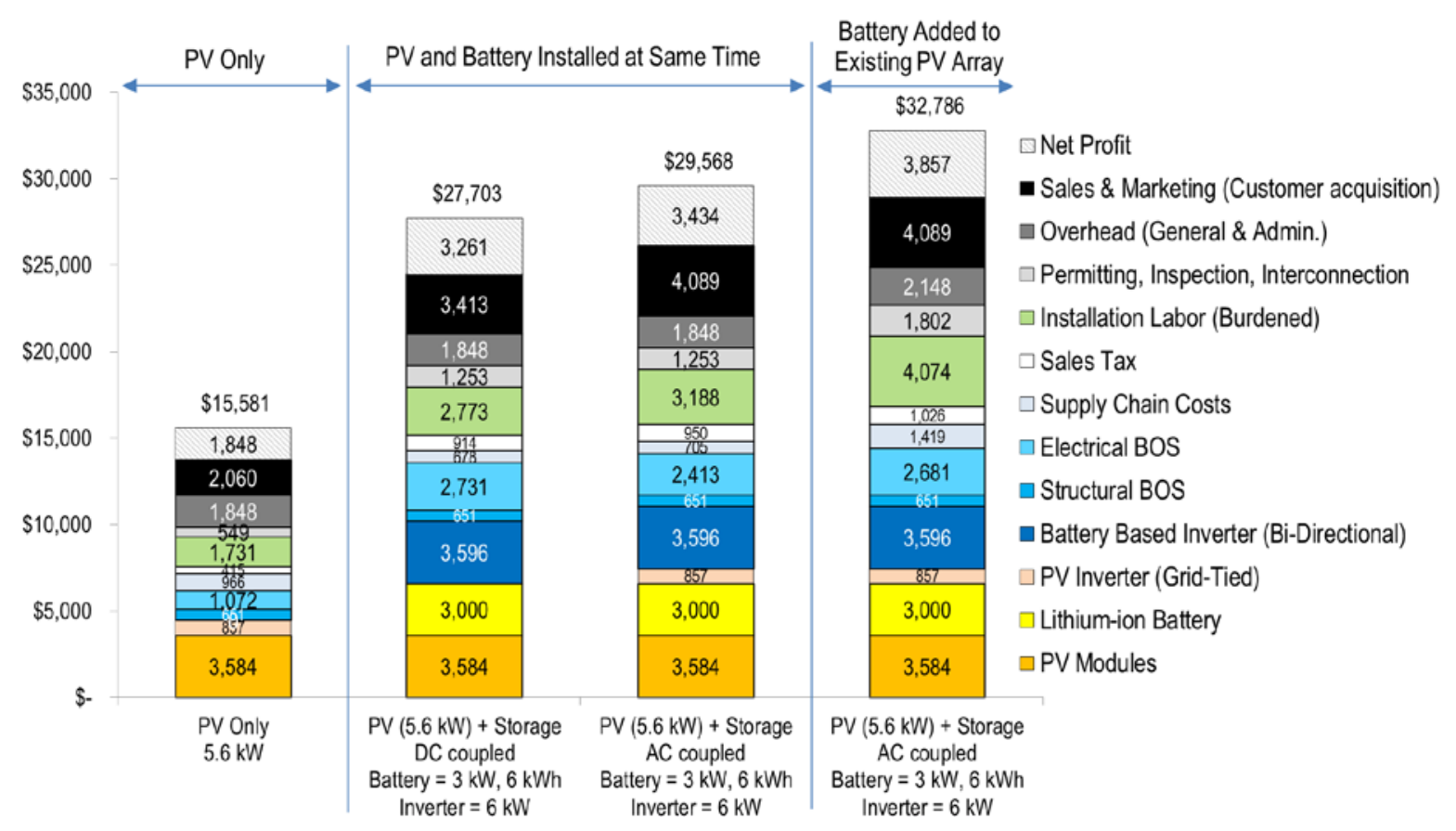

Figure ES-1. Modeled total installed cost and price components for residential PV-plus-storage systems, small-battery case (2016 U.S. dollars)

The large-battery case - which uses a 5.6-kW PV array and a 5-kW/20-kWh lithium-ion battery system - is designed to meet greater back-up power $(\mathrm{kW})$ and energy $(\mathrm{kWh})$ requirements in the event of a grid outage and enable a typical customer to optimize self-consumption of PV electricity including peak-demand shaving and time-of-use shifting (Figure ES-2). With DC coupling, the price of the large-battery system is $\$ 45,237$, which is $\$ 17,534(63 \%)$ higher than the small-battery system. With AC coupling, the price of the large-battery system is $\$ 47,171$, which is $\$ 17,603(60 \%)$ higher than the small-battery system price. The premium is due to the higher battery and inverter costs for the $5-\mathrm{kW} / 20-\mathrm{kWh}$ battery pack plus indirect cost multipliers (profit, sales tax, and supply-chain costs). 


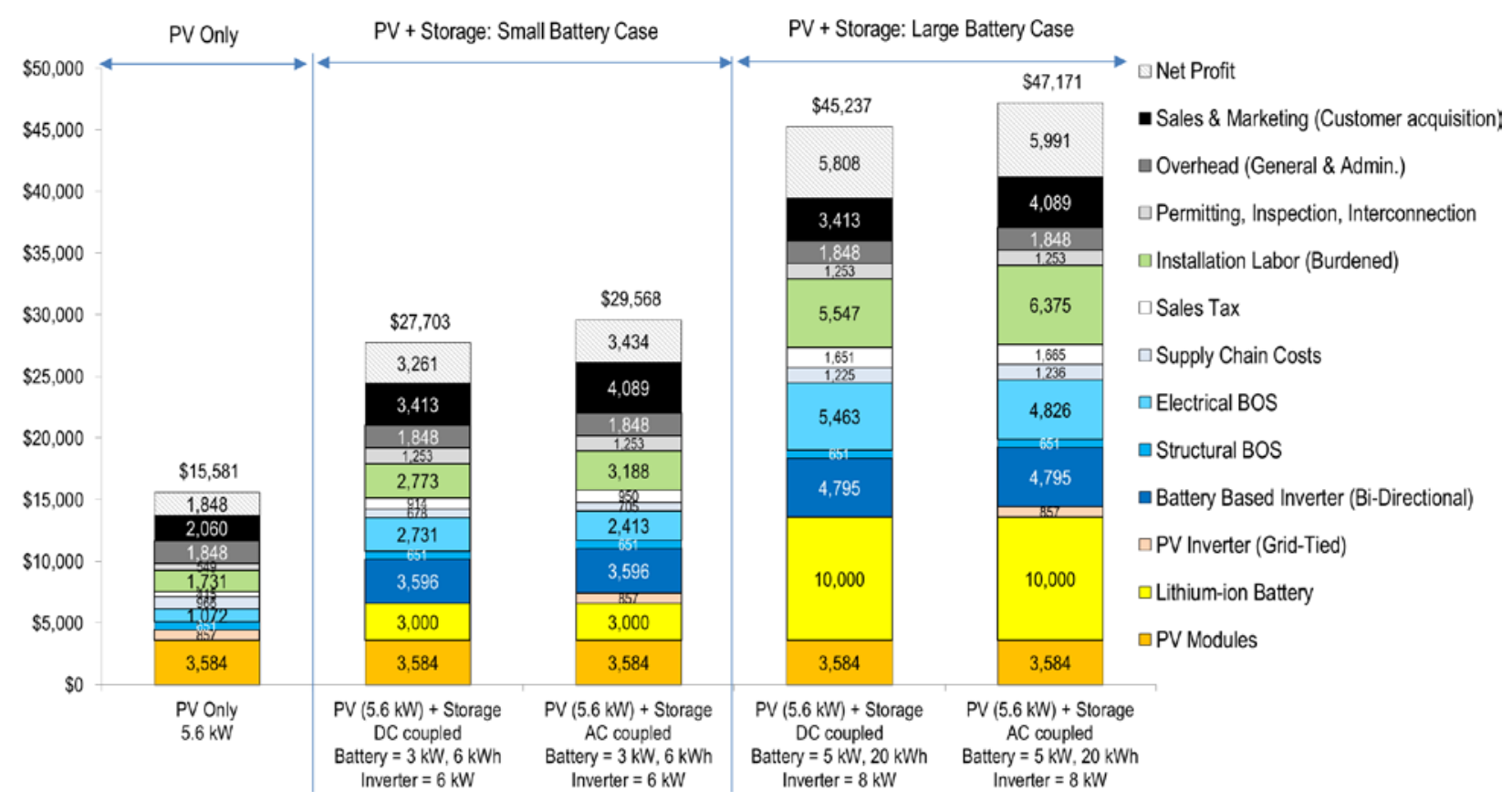

Figure ES-2. Modeled total installed cost and price components for residential PV-plus-storage systems, small-battery case vs. large-battery case (2016 U.S. dollars)

Hardware costs constitute about half the total price of our small-battery systems. The largest single hardware cost for these systems is the $6-\mathrm{kW}$ battery-based inverter $(\$ 3,596)$, followed by the PV array $(\$ 3,584)$ and the lithium-ion battery $(\$ 3,000)$. For our large-battery systems, hardware costs constitute about $60 \%$ of the total price, with the $\$ 10,000$ battery dominating the hardware cost contribution, followed by electrical BOS $(\$ 4,826-\$ 5,463)$ and the $8-\mathrm{kW}$ batterybased inverter $(\$ 4,795)$. The ranking of soft cost contributions varies by system configuration/application, with major contributions for all systems from net profit, sales and marketing, and installation labor.

Our modeling helps to quantify the component cost and system price barriers to deployment of PV-plus-storage. In the report, we also examine barriers beyond what we captured in the modeling, including those related to complex and inconsistent permitting processes, timeconsuming and restrictive interconnection and net-metering requirements, inadequate valuation of storage's benefits, constrained government incentives, and flat utility rates. As we continue to benchmark PV-plus-storage component costs and system prices, we will incorporate insights into these barriers to refine our modeling while building a better understanding of the value barriers to deployment. Finally, future work will include a more comprehensive approach to analyzing the combination of PV and storage, moving beyond electrical battery storage alone to consider a wide range of options that enable energy storage and dispatch, such as controllable domestic water heaters and controllable heating, ventilation, and air-conditioning systems. 


\section{Table of Contents}

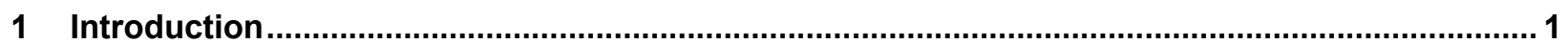

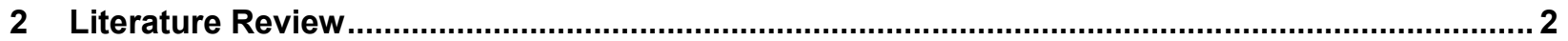

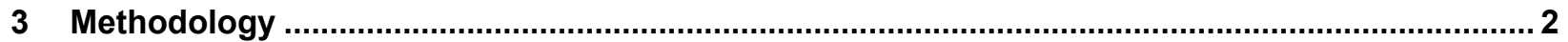

4 Common Configurations for Residential PV-Plus-Storage Systems: AC vs. DC Coupling.......... 3

5 Residential Storage Cost Metrics and Hardware Cost Comparison ........................................... 7

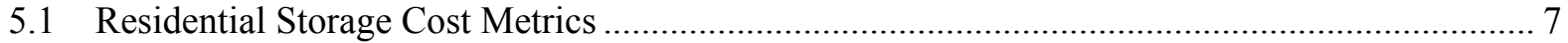

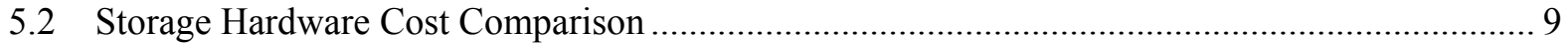

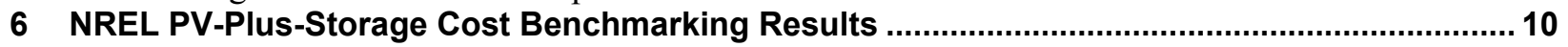

6.1 PV-Plus-Storage Cost Benchmark: Small-Battery Case ..................................................... 11

6.2 PV-Plus-Storage Cost Benchmark: Small-Battery Case vs. Large-Battery Case ....................... 12

7 Other Barriers to Residential PV-Plus-Storage Systems ....................................................... 16

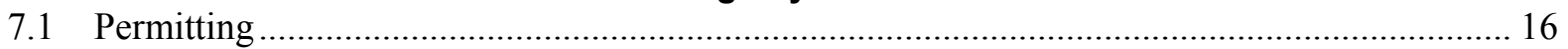

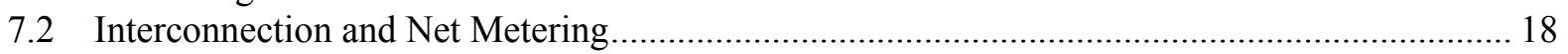

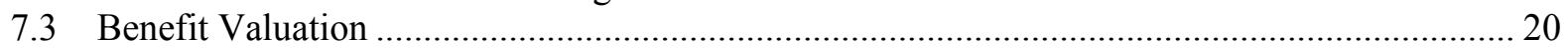

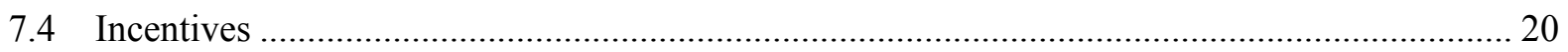

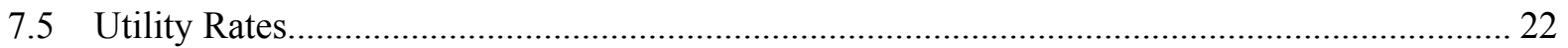

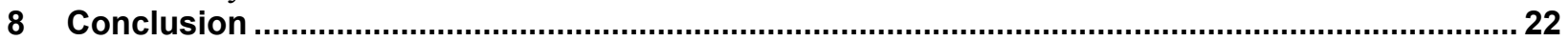

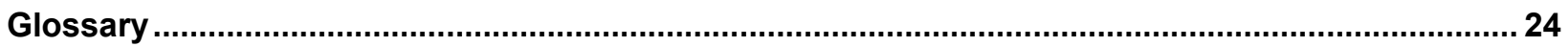

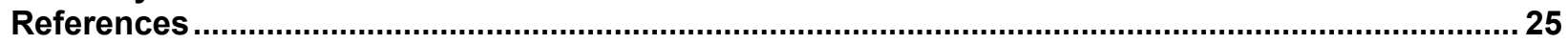

Appendix A: NREL-RMI Interview Questions Used for Data Collection .......................................... 28

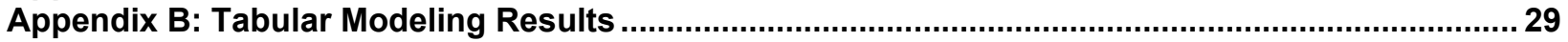




\section{List of Figures}

Figure ES-1. Modeled total installed cost and price components for residential PV-plus-storage systems, small-battery case (2016 U.S. dollars) vii

Figure ES-2. Modeled total installed cost and price components for residential PV-plus-storage systems, small-battery case vs. large-battery case (2016 U.S. dollars) viii

Figure 1. Modeled DC- and AC-coupled system configurations (simplified for illustrative purposes) ....... 4

Figure 2. Energy paths for DC- and AC-coupled systems in a PV consumption application...................... 5

Figure 3. Energy paths for DC- and AC-coupled systems in a storage application.................................. 5

Figure 4. Illustrative load profiles of "high peak" and "long-duration discharge" customers ..................... 8

Figure 5. Total hardware costs (2016 \$U.S.) calculated for a standard 3-kW/6-kWh residential storage system based on NREL modeling and three studies (Manghani 2014, Jaffe 2016, Lazard 2015)

Figure 6. Modeled total installed cost and price components for residential standalone PV and PV-plusstorage systems, small-battery case (2016 U.S. dollars)

Figure 7. Modeled total installed cost and price components for residential PV-plus-storage systems, small-battery case vs. large-battery case (2016 U.S. dollars) ................................................ 14

Figure 8. Schematic of energy storage permitting process in New York City, based on CUNY (2015)... 18

\section{List of Tables}

Table 1. Key Differences and Considerations for DC- vs AC-Coupled System Configurations

Table 2. Summary of PV-Plus-Storage Cost and Price Categories, Modeled Values, and Category

Descriptions

Table 3. Example PV-Plus-Storage Permitting Considerations.

Table 4. Interconnection Requirements by Storage Device Size in California....

Table 5. Summary of Modeled PV and PV-Plus-Storage Installed Price Benchmarks

Table B-1. Itemized Cost and Price Components for Residential PV-Plus-Storage Systems, Small-Battery

Case (2016 U.S. Dollars)

Table B-2. Itemized Cost and Price Components for Residential PV-Plus-Storage Systems: Small-Battery

Case vs. Large-Battery Case

30 


\section{Introduction}

As U.S. deployment of solar photovoltaic (PV) and wind technologies has grown rapidly in recent years, various stakeholders have become increasingly interested in enhancing the value of these variable-generation resources by deploying energy storage systems. For example, California, Massachusetts, Oregon, Washington, and New York City have set energy storage procurement targets or otherwise supported the deployment of storage. California's energy storage mandate carves out 200 megawatts (MW) of customer-side storage as part of its overall target of 1,325 MW by 2020 (CPUC 2013).

Increasingly low-cost customer-side energy storage products have the potential to optimize the value of rooftop PV while increasing the flexibility of electricity consumers and enhancing grid operations. ${ }^{5}$ Today, deployment of storage systems in the U.S. residential sector is lagging behind deployment in the commercial, industrial, and utility-scale sectors. Of the total $226 \mathrm{MW}$ of energy storage deployed in 2015, less than $35 \mathrm{MW}$ were behind the meter, and only about 4 MW were residential (GTM 2016a). However, analysts believe this ratio will change, estimating that $49 \%$ of total annual storage installations by 2021 will be behind the meter, including 463 MW in the residential sector (GTM 2016a). Further, the percentage of residential PV systems coupled with storage is projected to grow from $0.11 \%$ in 2014 to 3\% in 2018 (GTM 2016a).

The costs of lithium-ion batteries, which are common in grid-tied residential storage systems, fell by an average of $23 \%$ per year from 2010 to 2015, and continued cost reductions contribute to the projections of higher storage deployment in the future (Deloitte 2015, GTM 2016a). Still, the costs of residential storage systems remain high relative to the value proposition of these systems - in part due to regulatory and market barriers that impede deployment of storage systems (e.g., see Bhatnagar et al. 2013, Fitzgerald et al. 2015).

In this report, we fill a gap in the existing knowledge about PV-plus-storage system costs, prices, and value by providing detailed component-level cost and system-level price benchmarks for residential installations. We also examine other barriers to increased deployment of PV-plusstorage systems in the residential sector. The results are meant to help technology manufacturers, installers, and other stakeholders identify cost-reduction opportunities and inform decision makers about regulatory, policy, and market characteristics that impede PV-plus-storage deployment. In addition, our periodic benchmarks will document reductions in component costs and system prices over time.

The remainder of this report is organized as follows. Section 2 reviews the existing literature on distributed PV-plus-storage costs and deployment barriers. Section 3 describes our methodology. Section 4 discusses the common configurations for residential PV-plus-storage systems. Section 5 discusses the metrics used to measure the costs of PV-plus-storage systems and compares hardware costs across the literature. Section 6 presents the National Renewable Energy Laboratory's (NREL's) component cost and system price benchmarking results for residential

\footnotetext{
${ }^{5}$ In this report, storage refers to electrical battery storage (e.g., lithium-ion and lead-acid batteries). However, the industry trend is toward a more comprehensive approach to energy storage using a wide range of bundled technology offerings, such as domestic water heaters and controllable heating, ventilation, and air-conditioning systems. This comprehensive approach to energy storage is a subject for future research.
} 
PV-plus-storage installations. Section 7 discusses other barriers to residential PV-plus-storage deployment, and Section 8 summarizes key conclusions and outlines areas for future research.

\section{Literature Review}

The PV-plus-storage literature to date has broadly categorized impediments to energy storage deployment into two groups: value and cost barriers. With respect to value, the potential for storage to provide grid services such as black start, voltage support, and transmission and distribution deferral has been well documented (Butler et al. 2003, Walawalkar et al. 2007, Fitzgerald et al. 2015). However, the absence of actual markets for such services, in most parts of the United States, prevents full realization of the value of energy storage applications and undermines the economics of storage (Bhatnagar et al. 2013, Chang et al. 2014, Fitzgerald et al. 2015). Where limited markets do exist, outdated revenue mechanisms tend to undervalue energy storage (Sioshansi et al. 2012, Bhatnagar et al. 2013, Chang et al. 2014), and traditional energyvaluation metrics serve poorly for energy storage applications (Sioshansi et al. 2012, Denholm et al. 2013). Furthermore, outdated regulations reduce the certainty of energy storage valuation and prevent market access (Bhatnagar et al. 2013, Ecofys 2014).

With respect to costs, technology costs are among the primary barriers to wide-scale energy storage deployment (Bhatnagar et al. 2013). Recent reports provide component-level cost breakdowns for grid-scale storage (GTM 2016a, Jaffe 2016) and capital costs for grid-scale and distributed storage (Lazard 2015). However, few reports include detailed cost breakdowns for distributed storage (Manghani 2014, BNEF 2016, Jaffe 2016), and these reports primarily provide industry self-reported costs with little granularity. The lack of detailed cost information limits the analysis of cost drivers and cost-reduction opportunities. This report helps fill that gap.

\section{Methodology}

To analyze component costs and system prices for PV-plus-storage installed in the first quarter of 2016, we adapt NREL's component- and system-level modeling approach for standalone PV. Since 2010, NREL has benchmarked PV system prices for the residential, commercial, and utility-scale sectors (Goodrich et al. 2012, Ardani et al. 2012, Chung et al. 2015, Fu et al. 2016). Our methodology includes bottom-up accounting for all component and project-development costs incurred when installing residential systems, and it models the cash purchase price for such systems excluding the investment tax credit (ITC).

All hardware benchmarks represent the typical average selling price (ASP) between Tier 1 equipment suppliers and first buyers in the global market. Generally, first buyers of equipment ex-factory gate can be developers, EPC (engineering, procurement, and construction) contractors, installers, distributors, retailers, or other end users. Specifically, in our model, costs are represented from the perspective of the installer; thus, all hardware benchmarks represent the ASP at which components are purchased by the installer. Importantly, we also apply a $17 \%$ fixed margin to all direct costs to model the sales price paid by the end user to the installer. This $17 \%$ fixed margin is referred to as "net profit" and is added to total installed costs as a separate category. Although we include assumptions for indirect costs such as business overhead, supplychain costs, and regulatory costs, we do not include any additional end-user price gross-up, which is common in the marketplace. We use this approach owing to the wide variation in 
installer profits ${ }^{6}$ in the residential sector, where project pricing is highly dependent on region and project specifics such as local retail electricity rate structures, local rebate and incentive structures, competitive environment, and overall project or deal structures.

In general, we attempt to model typical installation techniques and business operations with an approach that enables benchmarking of costs independent from price, which is critical in understanding industry progress in reducing costs over time. Our methodology provides a granular accounting for all direct and indirect costs and captures variation driven by multiple factors. For example, we capture cost variation driven by different system designs, product specifications, and the intended end use of installed storage capacity.

In addition to our original analysis and model development, we derive inputs for our model and validate our draft results via interviews with industry and subject-matter experts. NREL, with support from the Rocky Mountain Institute, interviewed 22 representatives from 18 leading organizations closely involved with PV-plus-storage research, product development, and installation. Included were representatives from battery manufacturers, research organizations, inverter manufacturers, PV-plus-storage installation companies, project developers, industry associations, and utilities. Interview data geographically represent PV-plus-storage deployment and activities as identified in the Rocky Mountain Institute's prior research (Fitzgerald et al. 2015): most interviewees work in California or the Northeast, with some in Texas, Hawaii, and Colorado. Interview questions focused on gaining a deeper understanding of PV-plus-storage system configurations, costs, deployment challenges, future technology improvements and trends, and cost-model refinement and validation. Appendix A contains example questions from the interview survey. Our results highlight common themes from interviews, but individual participant information remains confidential. Finally, we also gathered data through published literature.

\section{Common Configurations for Residential PV-Plus- Storage Systems: AC vs. DC Coupling}

For this report, system configuration refers to four characteristics that determine a PV-plusstorage system's functionality:

- PV system capacity (kilowatts, $\mathrm{kW}$ )

- Battery energy capacity (kilowatt-hours, kWh)

- Battery power capacity $(\mathrm{kW})$

- Whether the battery is direct-current (DC) or alternating-current (AC) coupled ${ }^{7}$

Customer preference for specific characteristics is based on several factors, including cost, load profile, and planned use of the system for load shifting (storing energy in one period for use in a later period). In general, customers who have loads with high peaks of short duration may desire

\footnotetext{
${ }^{6}$ Profit is one of the differentiators between "cost" (aggregated expenses incurred by an installer to build a system) and "price" (what the end user pays for a system).

${ }^{7}$ NREL's modeled DC-coupled system includes a single dual-function inverter that is tied to both the PV array and the battery. In our AC-coupled system, to charge a battery, PV power is first converted (DC to AC) through a gridtied inverter and then converted (AC to DC) through a battery-based inverter.
} 
a high-power $(\mathrm{kW})$ battery capable of meeting the high peak. Customers who have flatter loads with lower peaks of longer duration may prefer a high-energy $(\mathrm{kWh})$ battery capable of longerduration energy discharge.

A PV array, a battery, and a battery-based inverter are the fundamental components of all PVplus-storage systems. Additional component requirements are determined by whether the system is DC or AC coupled ${ }^{8}$ : a DC-coupled system often requires a charge controller to step down the PV output voltage to a level that is safe for the battery, whereas an AC-coupled system requires a grid-tied inverter to feed PV output directly to the customer's load or the grid (Figure 1).

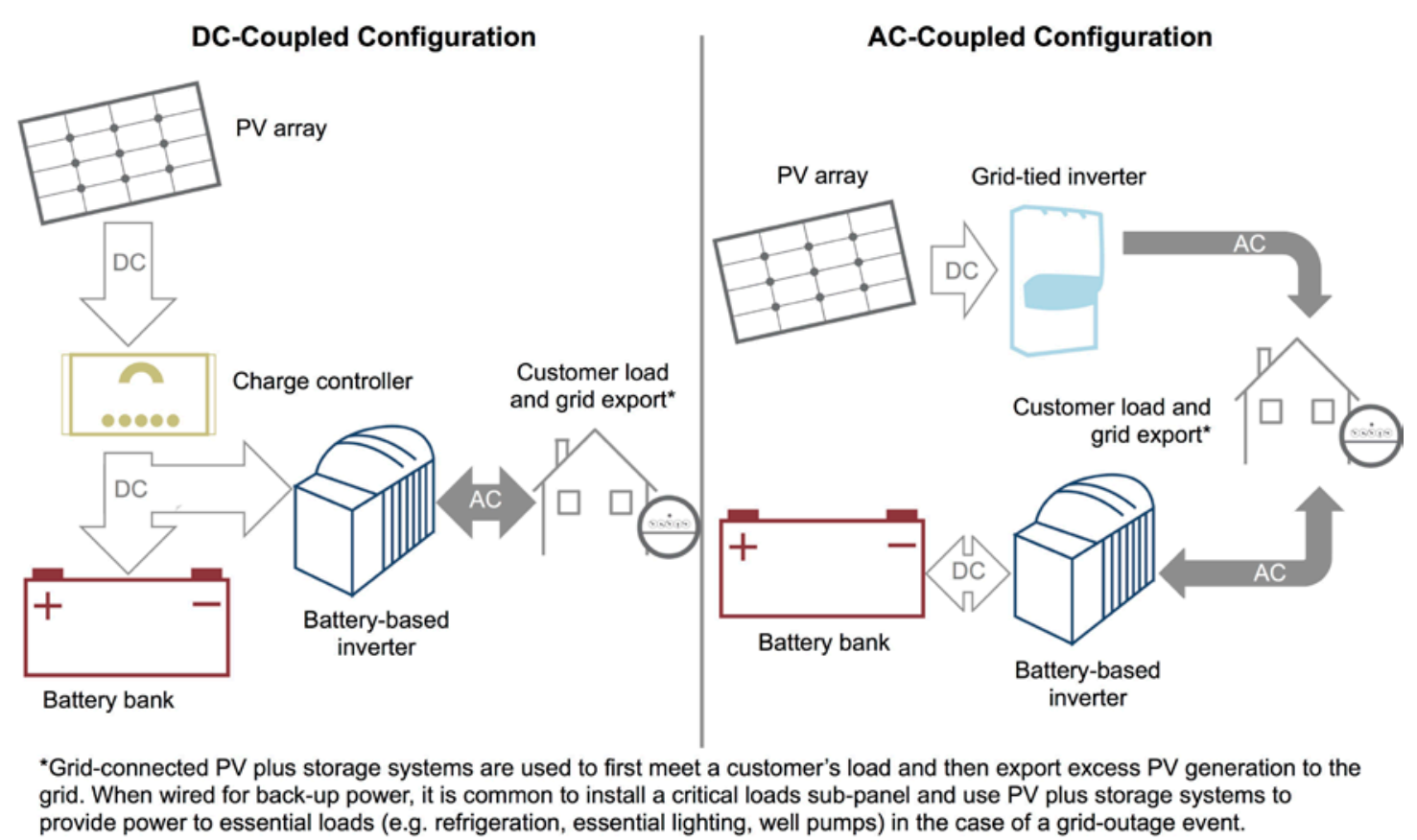

Figure 1. Modeled DC- and AC-coupled system configurations (simplified for illustrative purposes)

Each step in the energy paths illustrated in Figure 1 is associated with a power conversion and an associated efficiency loss. In other words, efficiency declines as the number of power conversions increases. The number of steps in the energy paths of DC- and AC-coupled systems varies depending on the primary use of the system. Importantly, our modeled DC-coupled system, depicted in Figure 1, includes a bi-directional, battery-based inverter because interviewees indicated that most DC-coupled systems today are installed with bi-directional inverters. However, a DC-coupled system does not necessarily require a bi-directional inverter unless the battery will charge from an AC power source (e.g., back-up generator, grid electricity).

Figure 2 illustrates the energy paths of DC- and AC-coupled systems when PV energy is used to directly power the customer's load at the time of generation. Generally, DC-coupled systems

\footnotetext{
${ }^{8}$ Our discussion is simplified to explain the basic technical differences between AC- and DC-coupled systems. However, the decision to use AC or DC coupling might also be driven by non-technical factors such as policy, contractual obligations, and economics.
} 
require a charge controller, which can decrease the overall efficiency of PV power delivery. ${ }^{9}$ Therefore, AC-coupled systems typically achieve a higher PV system efficiency than DCcoupled systems in applications where the customer will more frequently consume PV output directly at the time of generation (consumption applications). Further, based on stakeholder interviews, dual-function, battery-based inverters are generally less efficient than grid-tied PV inverters. As a result, a typical DC-coupled system is likely to be less efficient for PV consumption applications, even if the charge controller were removed.

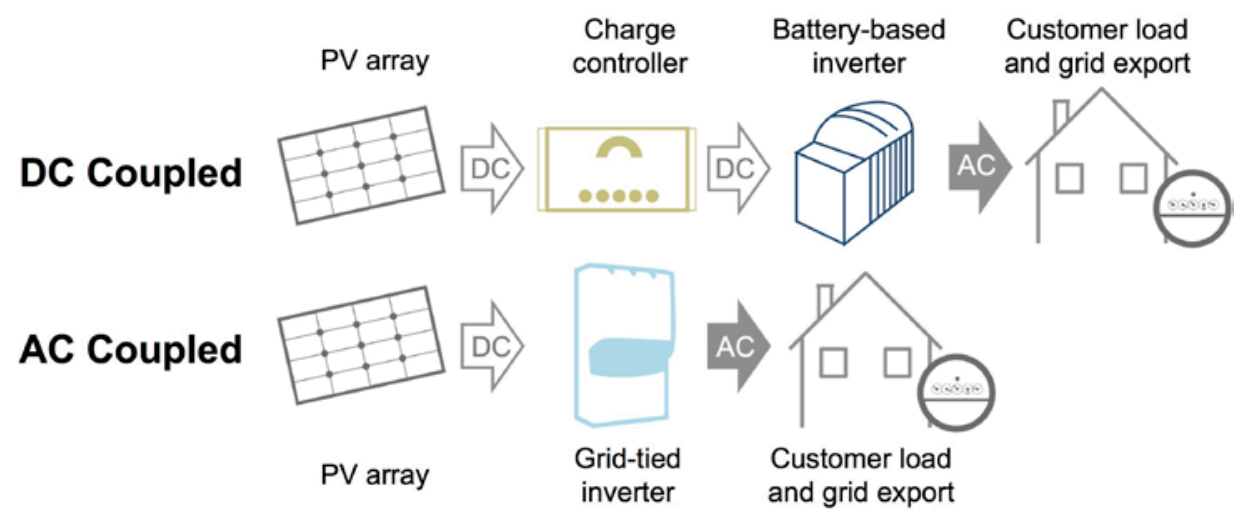

Figure 2. Energy paths for DC- and AC-coupled systems in a PV consumption application

Figure 3 illustrates the energy paths for DC- and AC-coupled systems when PV energy is stored and then used at a later time. DC-coupled systems require a single power conversion to store energy, whereas AC-coupled systems require two power conversions. Therefore, DC-coupled systems are generally more efficient than AC-coupled systems in applications where the customer will more frequently store PV output in the battery for use at a later time (storage applications). Based on typical weighted-average inverter efficiency from the California Energy Commission (CEC) Database, conversion losses for battery charging with AC-coupled systems can be up to 10\% higher compared to DC-coupled systems (CUNY 2016, CEC 2016).

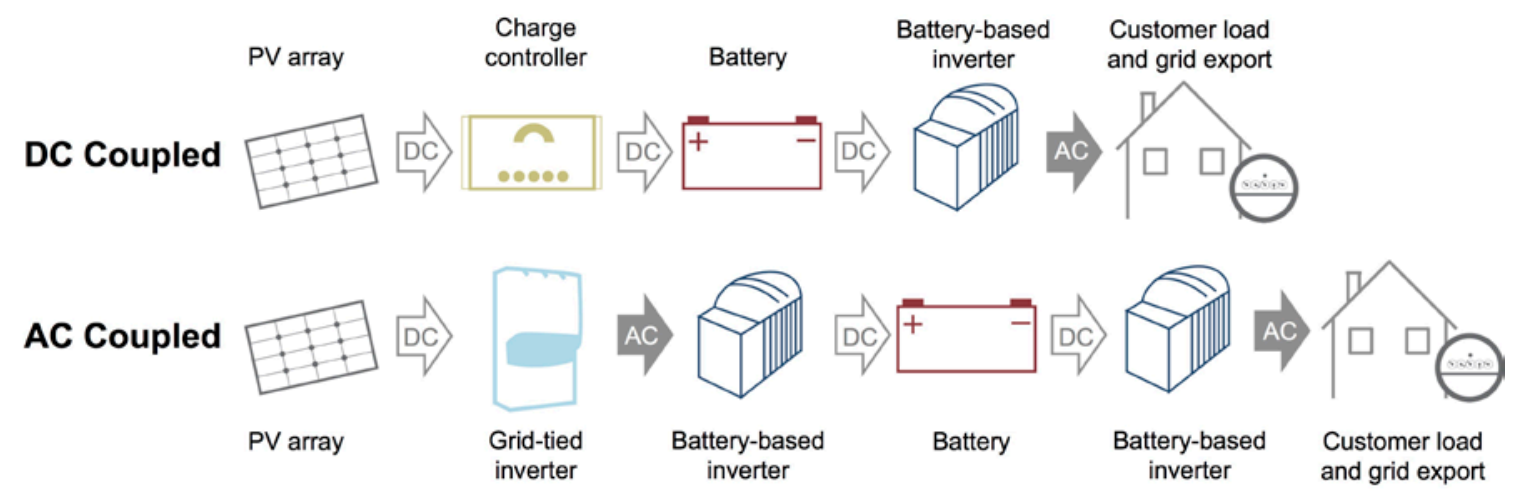

Figure 3. Energy paths for DC- and AC-coupled systems in a storage application

To summarize, based on the current state of technology, AC-coupled systems are generally more efficient in applications where PV energy is mostly used at the time of generation, and DC-

\footnotetext{
${ }^{9}$ Charge controllers step down the voltage of the PV DC output to a level that is safe for the battery. Chargecontroller efficiencies are generally greater than 90\% (Ryhd and Sanden 2005, Pierre-Olivier and Claude 2010).
} 
coupled systems are more efficient in applications where PV energy is mostly stored and used at a later time. Technological improvements to eliminate the need for the charge controller or increase the efficiency of battery-based inverters could reduce the efficiency gap between DCand AC-coupled systems in PV consumption applications. Table 1 summarizes key differences and considerations for DC- vs. AC-coupled configurations.

Table 1. Key Differences and Considerations for DC- vs AC-Coupled System Configurations

\begin{tabular}{|c|c|c|}
\hline Function & DC Coupled & AC Coupled \\
\hline $\begin{array}{l}\text { Inverter } \\
\text { requirements }\end{array}$ & $\begin{array}{l}\text { Typically requires a charge controller } \\
\text { to step down voltage of PV output to } \\
\text { the battery. Requires one inverter } \\
\text { shared between the battery and the } \\
\text { PV array. Although bi-directional } \\
\text { inverters are common, they are not } \\
\text { required. However, the customer } \\
\text { would be unable to charge the } \\
\text { battery from an AC source with a uni- } \\
\text { directional inverter. }\end{array}$ & $\begin{array}{l}\text { Requires two inverters: one grid-tied, uni- } \\
\text { directional inverter for the PV array and a } \\
\text { second, bi-directional battery-based inverter. } \\
\text { The bi-directional inverter makes it } \\
\text { technically possible for the customer to } \\
\text { charge the battery from the grid or other AC } \\
\text { source, although current investment (ITC) } \\
\text { guidelines can make it uneconomic to store } \\
\text { grid electricity (see section 7.4). }\end{array}$ \\
\hline $\begin{array}{l}\text { Wiring/conduit } \\
\text { requirements }\end{array}$ & $\begin{array}{l}\text { Typically requires less wiring than } \\
\text { AC-coupled systems. }\end{array}$ & $\begin{array}{l}\text { Typically requires more wiring than DC- } \\
\text { coupled systems, because the configuration } \\
\text { requires two inverters. }\end{array}$ \\
\hline $\begin{array}{l}\text { Installing PV and } \\
\text { battery at same } \\
\text { time vs. adding } \\
\text { battery to existing } \\
\text { PV array }\end{array}$ & $\begin{array}{l}\text { Most common configuration when PV } \\
\text { and battery are newly installed at the } \\
\text { same time, because DC coupling a } \\
\text { battery with an existing PV array } \\
\text { requires replacement of the PV } \\
\text { system's grid-tied inverter (with a } \\
\text { battery-based inverter) and } \\
\text { associated wiring. } \\
\text { Replacement of existing equipment } \\
\text { when DC-coupling storage with an } \\
\text { existing PV array often violates terms } \\
\text { of ownership agreements for third- } \\
\text { party-owned systems (CUNY } \\
\text { 2016). }\end{array}$ & $\begin{array}{l}\text { When AC-coupling storage with an existing } \\
\text { PV array, the existing grid-tied inverter can } \\
\text { remain in the installation without rewiring the } \\
\text { array. However, original PV net energy } \\
\text { metering and third-party financing } \\
\text { agreements are often placed at risk, and a } \\
\text { new utility interconnection agreement is } \\
\text { required if the battery system will operate in } \\
\text { parallel with the grid. } \\
\text { Equipment compatibility is an important } \\
\text { consideration when adding storage to an } \\
\text { existing PV array because of varying product } \\
\text { specifications across manufacturers. For } \\
\text { example, product compatibility and } \\
\text { communication between the grid-tied } \\
\text { inverter and battery-based inverter is } \\
\text { important for managing PV output and } \\
\text { matching loads in the system (CUNY 2016). }\end{array}$ \\
\hline $\begin{array}{l}\text { Permitting and } \\
\text { interconnection }\end{array}$ & $\begin{array}{l}\text { When PV and storage systems are } \\
\text { installed at the same time, typically } \\
\text { only one permit and one } \\
\text { interconnection agreement are } \\
\text { required. }\end{array}$ & $\begin{array}{l}\text { Even when PV and storage systems are } \\
\text { installed at the same time, authorities having } \\
\text { jurisdiction and utilities may require the } \\
\text { battery and PV array to be permitted and } \\
\text { approved for interconnection separately. }\end{array}$ \\
\hline
\end{tabular}

\footnotetext{
${ }^{10} \mathrm{We}$ do not model the costs of adding a DC-coupled battery to an existing PV system, because this configuration is not commonly deployed owing to required inverter and associated wiring replacement and potential for violation of ownership agreement terms for third-party-owned systems.
} 


\begin{tabular}{|l|l|l|}
\hline Function & DC Coupled & AC Coupled \\
\hline System efficiency & $\begin{array}{l}\text { Generally more efficient in } \\
\text { applications where PV energy is most } \\
\text { often stored and used at a later time. }\end{array}$ & $\begin{array}{l}\text { Generally more efficient in applications } \\
\text { where PV energy is most often used at the } \\
\text { time of generation. }\end{array}$ \\
\hline Self-restarting & $\begin{array}{l}\text { A DC-coupled system can self-restart } \\
\text { even if the inverter shuts down from } \\
\text { low battery voltage, because the } \\
\text { charge controller can still charge the } \\
\text { batteries. }\end{array}$ & $\begin{array}{l}\text { Most AC-coupled systems are not self- } \\
\text { restarting if the battery-based inverter shuts } \\
\text { down because of low battery voltage. }\end{array}$ \\
\hline Incentives & $\begin{array}{l}\text { If using a bi-directional inverter, may } \\
\text { require more sophisticated } \\
\text { monitoring to demonstrate that the } \\
\text { percentage of electricity stored is } \\
\text { provided by PV versus the grid- } \\
\text { required for ITC and performance- } \\
\text { based incentive compliance. }\end{array}$ & $\begin{array}{l}\text { Allows for simple monitoring when installing } \\
\text { a one-way kWh meter to the output of the } \\
\text { grid-tied inverter. Batteries that are later } \\
\text { added to an existing PV array may be } \\
\text { eligible for the ITC if the batteries are } \\
\text { integral to the operation of the PV system } \\
\text { (Clean Energy Group 2016).11 }\end{array}$ \\
\hline
\end{tabular}

\section{Residential Storage Cost Metrics and Hardware Cost Comparison}

There is considerable confusion about how to define a standard set of cost metrics for energy storage. This section first explains the difficulty of arriving at a standard approach for reporting storage costs and then provides the rationale for using total installed system price as our primary metric rather than a metric normalized to system size. Second, this section compares NREL's cost-modeling results with the results of several other studies.

\subsection{Residential Storage Cost Metrics}

Energy-cost metrics are a means of comparing the costs of different energy systems and technologies in terms of standard units. For standalone PV, dollars per watt $(\$ / W)$ and levelized cost of energy (LCOE) are commonly used and relatively easy to interpret. However, the diversity of storage applications and end uses complicates energy storage cost comparisons, especially when reporting costs in terms of system size.

Storage system size is reported in terms of both storage system power capacity $(\mathrm{kW})$ and energy capacity $(\mathrm{kWh})$. Some systems are optimized to deliver high power capacity, whereas others are optimized for longer discharges through more energy capacity (Figure 4).

\footnotetext{
${ }^{11}$ Eligibility is based on guidance from Internal Revenue Service Private Letter Rulings.
} 


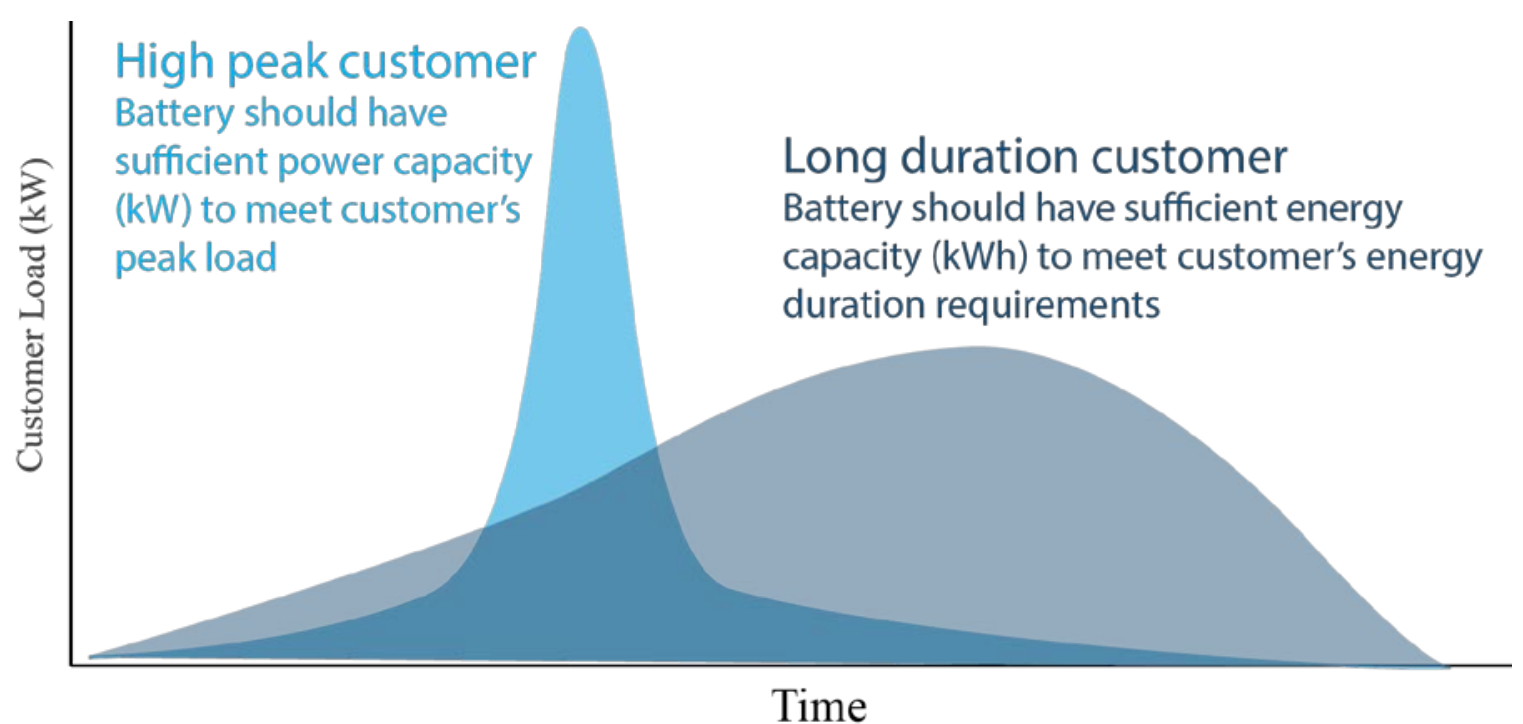

Figure 4. Illustrative load profiles of "high peak" and "long-duration discharge" customers

The amount of energy that a battery can store is determined by its energy capacity $(\mathrm{kWh})$, whereas the rate at which it charges or discharges is determined by its power rating $(\mathrm{kW})$. Although PV system cost is typically estimated based on power rating $(\mathrm{kW})$ alone, storage costs can be estimated based on capacity $(\mathrm{kWh})$, power $(\mathrm{kW})$, or both. This confounds the measurement and reporting of installed storage system costs based on system size. Measuring total storage system costs in $\$ / \mathrm{kWh}$ generally portrays favorable economics for high-energy systems, whereas measuring in $\$ / \mathrm{kW}$ generally favors high-power systems.

For example, assume the true unit cost of power components is $\$ 1,000 / \mathrm{kW}$, and the true unit cost of energy components is $\$ 1,000 / \mathrm{kWh}$. Consider two systems: system A has $5 \mathrm{~kW}$ of power capacity and $5 \mathrm{kWh}$ of energy capacity $(5 \mathrm{~kW} / 5 \mathrm{kWh})$, and system B has $5 \mathrm{~kW} / 10 \mathrm{kWh}$. The total cost of system A would be $\$ 10,000$, with implied unit costs of $\$ 2,000 / \mathrm{kW}$ or $\$ 2,000 / \mathrm{kWh}$. The total cost of system B would be $\$ 15,000$, with implied unit costs of $\$ 3,000 / \mathrm{kW}$ or $\$ 1,500 / \mathrm{kWh}$. These results suggest that system A is less costly than system B in terms of $\$ / \mathrm{kW}$ and costlier in terms of $\$ / \mathrm{kWh}$, although the underlying unit costs are identical. This distortionary effect could lead to the conclusion that one system is more economical or less economical than another when, in reality, the only difference is a change in the power-to-energy capacity ratio.

To address this distortionary effect, some studies report storage costs in both $\$ / \mathrm{kW}$ and $\$ / \mathrm{kWh}$ by assigning the power components of the system (e.g., inverter, balance of system [BOS]) to the power metric of $\$ / \mathrm{kW}$ and the energy components of the system (e.g., battery) to the energy metric of $\$ / \mathrm{kWh}$. The challenge with this approach is consistently defining the power and energy components of storage systems to avoid variability in cost reporting across different studies. The usefulness of storage cost metrics for comparison purposes is limited by the sensitivity of the metrics to the storage application and the definition of power versus energy components; therefore, we report total installed system price as our primary metric. 


\subsection{Storage Hardware Cost Comparison}

Several studies report 2015 hardware costs for residential energy storage systems, but comparing results across studies is complicated by different system sizes and different information provided in each study. Here, we convert the values from these studies to hardware costs for a standard system size of $3 \mathrm{~kW} / 6 \mathrm{kWh}$, and we compare the results with hardware costs for such a system estimated via NREL's modeling method. We standardize to a 3-kW/6-kWh system size based on our interviews, which suggest that this size is among the most common at the residential scale. The values shown here do not include the PV component of PV-plus-storage systems.

GTM (Manghani 2014) reports "total capital costs" for the hardware components of a 5-kW/5$\mathrm{kWh}$ residential storage system. It breaks the per-unit costs down as $\$ 470 / \mathrm{kWh}$ for the battery and $\$ 1,692 / \mathrm{kW}$ for BOS costs. Applying these per-unit costs to our standard 3-kW/6-kWh system yields a hardware cost of $\$ 7,896$.

Jaffe (2016) reports costs for the hardware components of a 1.3-kW/6.4-kWh system. We calculate the per-unit costs by dividing the costs of the battery-related components by the system's energy capacity $(6.4 \mathrm{kWh})$ and dividing the costs of the other hardware components by the system's power capacity $(1.3 \mathrm{~kW})$. This results in per-unit costs of $\$ 560 / \mathrm{kWh}$ and $\$ 1,702 / \mathrm{kW}$. Applying these costs to our standard 3-kW/6-kWh system yields a hardware cost of $\$ 8,466 .{ }^{12}$

Lazard (2015) reports high and low values for the hardware "installed capital costs" of a 5$\mathrm{kW} / 10-\mathrm{kWh}$ system. Because the high values are far greater than other estimates, we use the low values, which are more consistent with the other estimates. The reported battery cost is $\$ 471 / \mathrm{kWh}$, and the reported total cost is $\$ 1,088 / \mathrm{kWh}$. We estimate other hardware costs on a per-kW basis as the difference between the implied total system cost and the implied total battery cost, for a value of $\$ 1,234 / \mathrm{kW} .{ }^{13}$ Applying these per-unit costs to our standard 3-kW/6-kWh system yields a hardware cost of $\$ 6,528$.

Finally, we model the installed hardware cost for a 3-kW/6-kWh residential storage system using our detailed analytical method. This results in a total hardware cost of $\$ 8,559$. Figure 5 compares the hardware costs from the extant literature and NREL's modeling results for our standard 3$\mathrm{kW} / 6-\mathrm{kWh}$ system. The values are reasonably consistent, although significant uncertainty exists with respect to the different ways information is provided in each study and the various assumptions about the hardware included. For example, NREL's model assumes the use of a bidirectional, battery-based inverter that can operate in on-grid and off-grid modes, which results in higher costs in the "other hardware" category relative to other estimates.

\footnotetext{
${ }^{12}$ Jaffe (2016) also includes price estimates for an energy management system, fire suppression, fire detection, enclosure, and thermal management system. However, we exclude these prices here because it is unclear whether GTM and Lazard account for such components. Further, it is unclear whether normalizing to a per-unit $(\$ / \mathrm{kW})$ cost is appropriate for these items. Normalization implies a linear relationship between costs and the normalizing metric $(\mathrm{kW})$, but a linear relationship between power $(\mathrm{kW})$ and the costs of components, such as an energy management system and fire detection, is not obvious.

${ }^{13}$ Total system cost $=\$ 1,088 / \mathrm{kWh} \times 10 \mathrm{kWh}=\$ 10,880$

Total battery cost $=\$ 471 / \mathrm{kWh} \times 10 \mathrm{kWh}=\$ 4,710$

Total other hardware cost $=\$ 10,880-\$ 4,710=\$ 6,170$

Normalized other hardware cost $=\$ 6,170 / 5 \mathrm{~kW}=\$ 1,234 / \mathrm{kW}$
} 


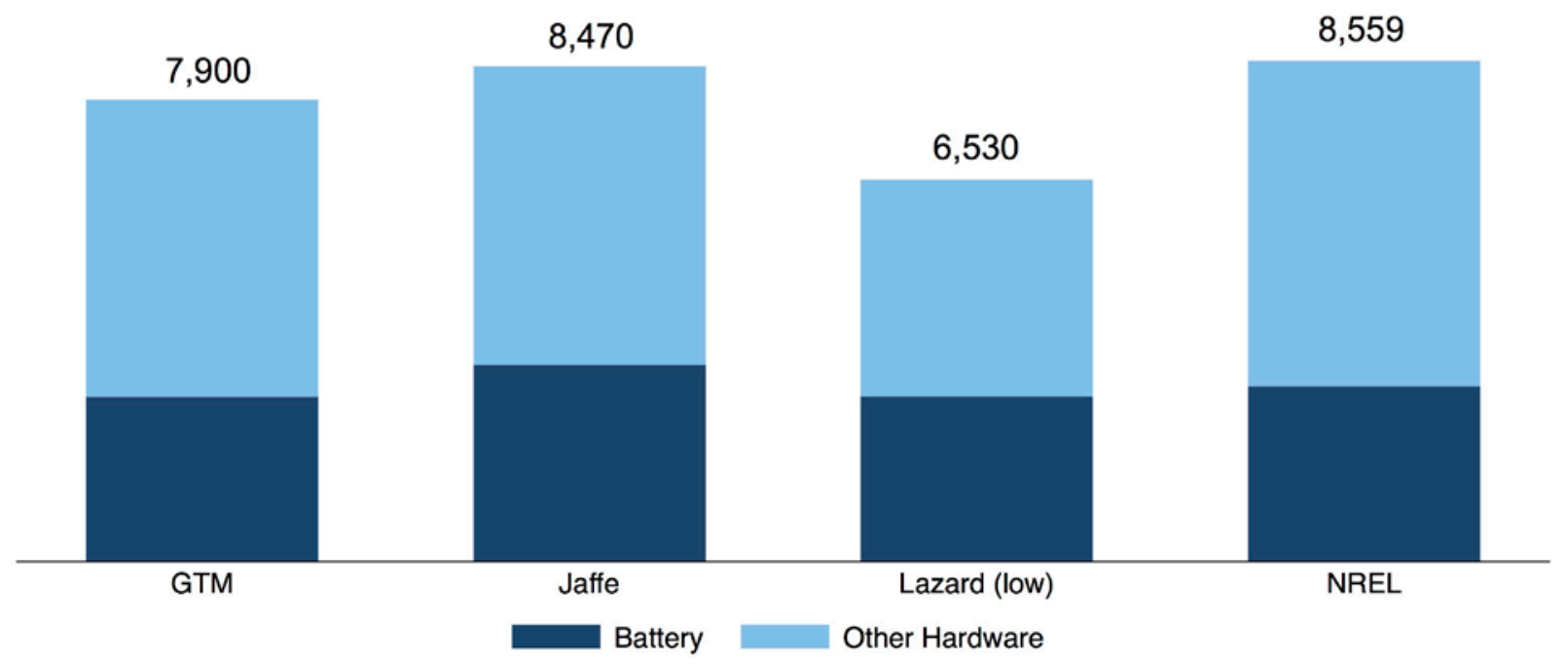

Figure 5. Total hardware costs (2016 \$U.S.) calculated for a standard 3-kW/6-kWh residential storage system based on NREL modeling and three studies (Manghani 2014, Jaffe 2016, Lazard 2015)

Our estimates focus on hardware costs, because non-hardware — or "soft" — costs are largely absent from the energy storage literature. Jaffe (2016) provides the most detailed breakdown of storage soft costs to date. However, it is difficult to normalize the Jaffe (2016) soft-cost estimates for comparison purposes without knowing what portion of these costs is fixed; thus, we do not compare soft costs across the literature. In the next section, we use NREL's modeling method to generate detailed PV-plus-storage component cost and system price breakdowns, which have been unavailable in the literature to date.

The estimates in Figure 5 and the NREL benchmarking results in Section 6 are based on historical data and represent the current state of installed residential-scale energy storage costs. However, the residential-scale energy storage market is highly dynamic, and estimates in Figure 5 are likely to be conservative estimates of future costs even in the near term. For example, one residential storage provider recently announced that the total installed price for a $7-\mathrm{kW} / 14-\mathrm{kWh}$ battery will start at $\$ 7,000$ in early 2017 , with $\$ 5,500$ for the battery and $\$ 1,500$ for installation and BOS hardware (GTM 2016b). These estimates cannot yet be vetted with empirical data, but they may indicate future market trends toward increasingly lower soft costs and aggressive pricing strategies.

\section{NREL PV-Plus-Storage Cost Benchmarking Results}

This section describes the results of NREL's detailed component cost and system price benchmarking analysis for DC- and AC-coupled PV-plus storage systems. Section 6.1 presents results for a 5.6-kW PV array plus a 3-kW/6-kWh storage system, with variations based on whether the PV and storage are installed simultaneously or separately. This type of system is designed for back-up of critical loads and self-consumption of electricity, including peak- 
demand shaving and time-of-use shifting, but may also be used for arbitrage in some areas. ${ }^{14}$ Section 6.2 compares this "small-battery" system with a larger storage system $(5 \mathrm{~kW} / 20 \mathrm{kWh})$ designed to meet greater back-up power $(\mathrm{kW})$ and energy $(\mathrm{kWh})$ requirements in the event of a grid outage, in addition to PV self-consumption. We refer to the larger storage system as the "large-battery" case.

\subsection{PV-Plus-Storage Cost Benchmark: Small-Battery Case}

System configuration is highly dependent on the unique characteristics of each residence and the intended use of the PV-plus-storage system. For the small-battery system modeled here, we assume a 5.6-kW PV array and a 3-kW/6-kWh lithium-ion battery. We analyze DC- and ACcoupled configurations when the PV array and storage are installed simultaneously, and we analyze an AC-coupled configuration when the battery is added later to an existing PV system. We model the PV array size $(5.6 \mathrm{~kW})$ and battery size $(3 \mathrm{~kW} / 6 \mathrm{kWh})$ based on stakeholder interview findings related to common residential system sizes. Assuming about $4 \mathrm{kWh}$ of daily battery energy discharge, ${ }^{15}$ the battery could meet about 2 hours of the daily peak electricity demand of a typical household, or up to 4 hours of off-peak electricity demand. ${ }^{16}$ Homeowners who want a longer duration of back-up power during a grid outage could limit demand to a set of critical loads, or they could purchase a larger storage system (see Section 6.2).

Figure 6 shows our cost benchmarking results for new DC- and AC-coupled systems (when PV and storage are installed simultaneously) and AC-coupled systems with the storage system retrofitted after the PV array. The DC-coupled system price $(\$ 27,703)$ is lower than the ACcoupled system price $(\$ 29,568)$ for a new/simultaneous PV-plus-storage installation. The price premium for AC-coupled systems is mainly due to higher hardware, labor, and sales and marketing costs associated with the additional grid-tied inverter and more complex system design and engineering requirements (see Section 4).

Our modeled DC- and AC-coupled configurations assume the use of identical 6-kW, 48-volt, bidirectional, battery-based inverters $(\$ 3,596)$. This inverter selection does not require the use of DC optimizers. Based on current product offerings, we estimate the cost of a similarly sized inverter that requires the use of DC optimizers to be $\$ 3,620$ - well within the cost range of our modeled inverter selection. ${ }^{17}$

\footnotetext{
${ }^{14}$ In some utility service territories, including in California investor-owned utilities, PV electricity that is eligible for net metering can be stored in batteries and then sold to the grid during high-rate periods.

${ }^{15}$ Based on a typical depth of discharge of about $80 \%$ and an inverter efficiency of about $90 \%$.

${ }^{16}$ The average American household uses $30 \mathrm{kWh} /$ day, or about $1.25 \mathrm{kWh}$ per hour on average throughout the day. Assuming a peak load of double the average hourly consumption $(2.5 \mathrm{kWh}$ per hour $), 4 \mathrm{kWh}$ of stored energy could meet this peak demand for 1.6 hours. Assuming an off-peak load of $1 \mathrm{kWh}$ per hour, $4 \mathrm{kWh}$ could operate for 4 hours. These calculations assume the PV system is not generating (e.g., in the evening).

${ }^{17}$ Estimate based on total cost of DC optimizers and Solar Edge SE7600A-USS Powerwall-compatible 7.6-kW StorEdge inverter.
} 


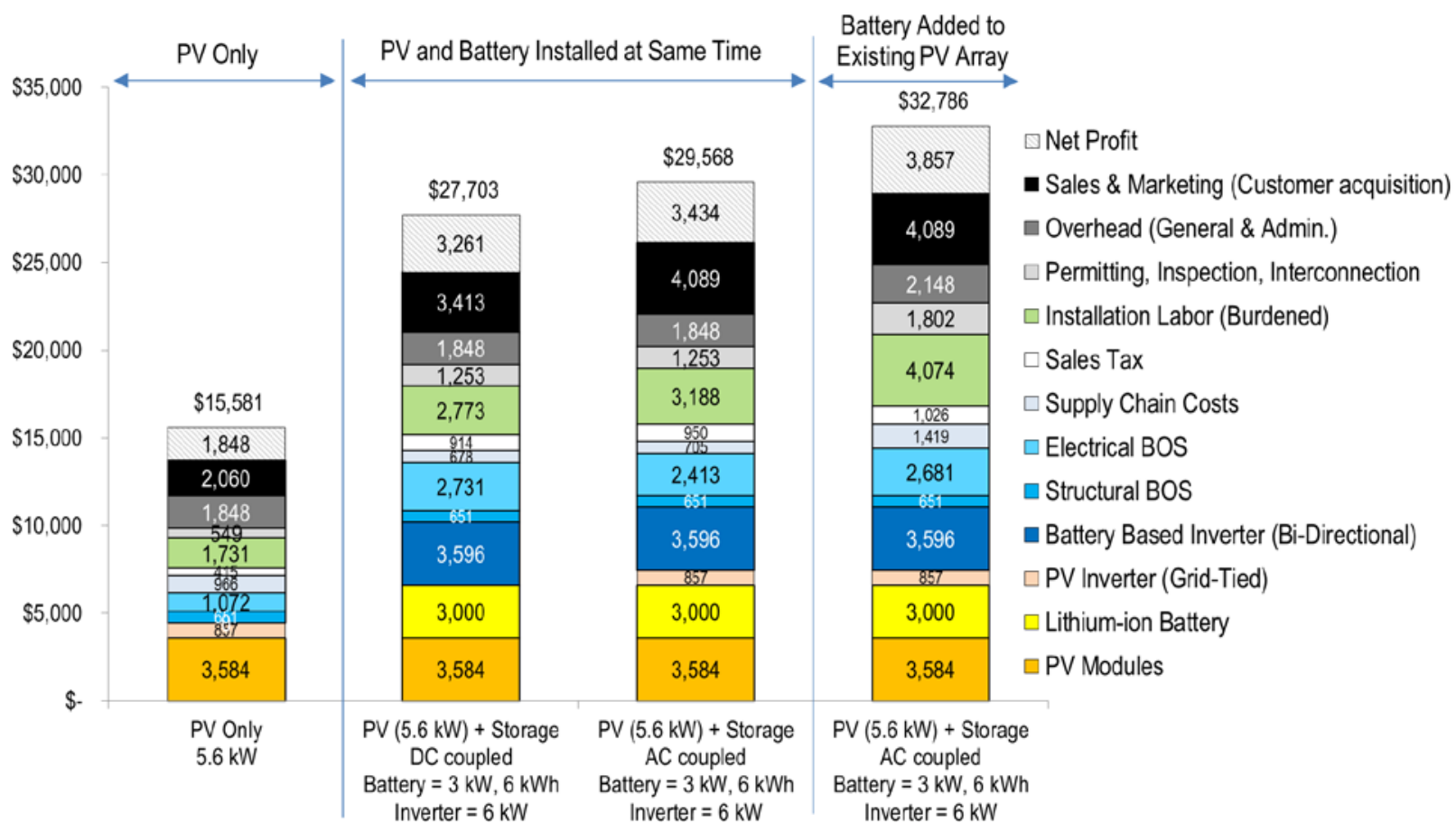

Figure 6. Modeled total installed cost and price components for residential standalone PV and PVplus-storage systems, small-battery case (2016 U.S. dollars)

Figure 6 also shows a benchmark installed price of $\$ 32,786$ for an AC-coupled system when the battery is added later to an existing PV array, which is $\$ 3,218$ higher than the price of installing the PV and storage simultaneously. ${ }^{18}$ The simultaneous installation results in savings related to installation labor and electrical wiring as well as indirect costs (supply chain costs, overhead, regulatory costs, and profit). Appendix B provides tabulated results.

We do not model the costs of adding a DC-coupled battery to an existing PV system, because this configuration is not commonly deployed. The costs of such a system would be inflated owing to required inverter and associated wiring replacement. In contrast, retrofitting a PV installation with an AC-coupled battery can use the existing grid-tied inverter and avoid additional rewiring. Further, DC coupling an existing PV array with a battery also requires a new interconnection agreement with the utility, and it might risk the net energy metering (NEM) agreement, PV equipment warranty, and lease or power-purchase agreement terms (for thirdparty-owned systems).

\subsection{PV-Plus-Storage Cost Benchmark: Small-Battery Case vs. Large- Battery Case}

Based on our industry interviews, a growing number of end users are willing to pay a premium for larger PV-plus-storage systems with enhanced back-up power capabilities owing to the

\footnotetext{
${ }^{18}$ This $\$ 3,218$ total incremental costs can be broken down as follows: $\$ 886$ for additional installation labor ( $\$ 169$ for site assessment and/or system design, $\$ 363$ for second truck roll, and $\$ 354$ for additional on-site electrician labor); \$549 for permitting, inspection, and interconnection, \$268 for electrical BOS hardware, and \$1,515 in profit, tax, supply-chain costs, and overhead.
} 
increased occurrence of superstorms and natural disasters. This decision may not always be economic given the relatively high costs of PV-plus-storage systems today; however, consumeradoption motivations extend beyond economics to concerns over security, safety, and resiliency (EuPD Research and GreenTech Media 2016).

When considering PV-plus-storage for enhanced back-up power, optimal system configurations and technology choices are determined by system application. We model a larger PV-plusstorage system (5.6-kW PV plus 5-kW/20-kWh storage) designed for daily PV self-consumption and enhanced back-up capabilities. The average U.S. home uses about $30 \mathrm{kWh}$ of electricity each day, with large variations based on location and season. Assuming an average household could cut its electricity use by two thirds in an emergency, it would need to meet $10 \mathrm{kWh}$ of demand each day. At this rate, our large-battery system could provide back-up electricity for an average of 35 hours without PV recharging. In contrast, our small-battery system (3-kW/6-kWh storage) could only provide back-up electricity for an average of 10 hours without PV recharging. ${ }^{19}$ If $30 \%$ of the PV system's average output were available to charge the battery each day, then the large-battery system could provide back-up electricity for about 4 days, compared with about 1 day for the small-battery system. ${ }^{20}$ The higher power of the large-battery system $(5 \mathrm{~kW})$ compared with the small-battery system $(3 \mathrm{~kW})$ would also enable the large-battery system to meet higher peak electricity demands during a grid outage (e.g., to run air conditioning).

Figure 7 compares PV-plus-storage system prices for systems designed for PV self-consumption and back-up emergency power with the use of a $3-\mathrm{kW} / 6-\mathrm{kWh}$ battery and $5-\mathrm{kW} / 20-\mathrm{kWh}$ battery. ${ }^{21}$ As Figure 7 shows, however, this benefit comes with a substantial price increase. With DC coupling, the price of the modeled larger system is $\$ 45,237$, which is $\$ 17,534(63 \%)$ more than the modeled smaller system. With AC coupling, the price of the large-battery system is $\$ 47,171$, which is $\$ 17,603(60 \%)$ higher than the price of the small-battery system. The premium is due to the larger systems' higher battery, inverter, BOS, and labor costs plus indirect costs (profit, sales tax, and supply-chain costs). Appendix B provides tabular results.

\footnotetext{
${ }^{19}$ These calculations assume $80 \%$ depth of discharge for the batteries and $90 \%$ inverter efficiency. Even in these simplified scenarios, the actual amount of time that the system could provide back-up electricity would depend on the battery's charge level and the time of day at the time of the outage as well as the home's load profile.

${ }^{20}$ This is based on results using NREL's PVWatts for a 5.6-kW PV system located in Denver. This modeled system generates $8,179 \mathrm{kWh}$ per year (average, $22.4 \mathrm{kWh}$ per day). Thus, we assume this same 5.6-kW PV array will generate an average of $6.7 \mathrm{kWh}$ per day when only $30 \%$ of the total PV resource is available owing to severe weather conditions.

${ }^{21}$ We assume that all batteries are installed inside the home. Installation of batteries outside would require additional BOS hardware, such as a concrete pad and associated container. This additional BOS hardware would add to the benchmarked price of our modeled systems.
} 


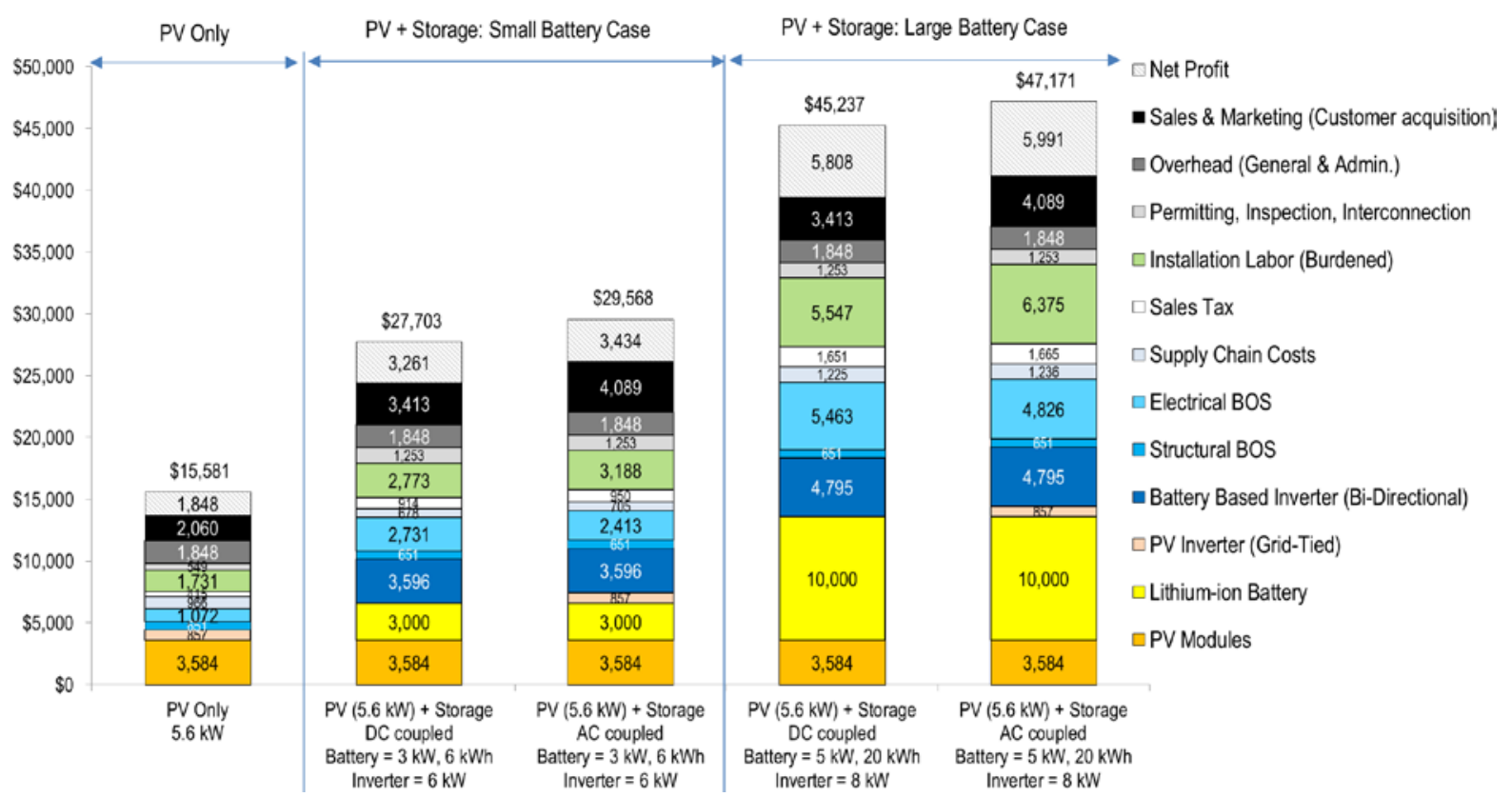

Figure 7. Modeled total installed cost and price components for residential PV-plus-storage systems, small-battery case vs. large-battery case (2016 U.S. dollars)

Table 2 provides a summary of cost and price categories, modeled values, and category descriptions.

Table 2. Summary of PV-Plus-Storage Cost and Price Categories, Modeled Values, and Category Descriptions

\begin{tabular}{|c|c|c|}
\hline Category & Modeled Value & Description \\
\hline Net profit & $17 \%$ & $\begin{array}{l}\text { Applies a fixed-percentage margin to all } \\
\text { direct costs including hardware, installation } \\
\text { labor, direct sales and marketing, design, } \\
\text { installation, and permitting fees. }\end{array}$ \\
\hline $\begin{array}{l}\text { Sales and } \\
\text { marketing } \\
\text { (customer } \\
\text { acquisition) }\end{array}$ & $\begin{array}{l}\$ 3,413 \text { (DC-coupled) } \\
\$ 4,089 \text { (AC-coupled) } \\
\text { Assumes higher costs for AC- } \\
\text { coupled systems due to more } \\
\text { complex system design and } \\
\text { engineering requirements. }\end{array}$ & $\begin{array}{l}\text { Total cost of sales and marketing activities } \\
\text { over the last year-including marketing and } \\
\text { advertising, sales calls, site visits and } \\
\text { assessment, bid and pro forma preparation, } \\
\text { system engineering and design, and } \\
\text { contract negotiation. }\end{array}$ \\
\hline $\begin{array}{l}\text { Overhead } \\
\text { (general \& } \\
\text { administrative) }\end{array}$ & $\begin{array}{l}\$ 1,848 \text { for all modeled } \\
\text { configurations and } \\
\text { applications except AC- } \\
\text { coupled retrofit }(\$ 2,148)\end{array}$ & $\begin{array}{l}\text { General and administrative expenses- } \\
\text { including fixed overhead expenses } \\
\text { covering payroll (excluding permitting } \\
\text { payroll), facilities, administrative, finance, } \\
\text { legal, information technology, and other } \\
\text { corporate functions as well as office } \\
\text { expenses. }\end{array}$ \\
\hline
\end{tabular}




\begin{tabular}{|c|c|c|}
\hline Category & Modeled Value & Description \\
\hline $\begin{array}{l}\text { Permitting, } \\
\text { inspection, } \\
\text { interconnection } \\
\text { (PII) }\end{array}$ & $\begin{array}{l}\text { Non-electrician labor } \\
\text { (burdened): } \$ 30.43 / \mathrm{h} \text { (BLS } \\
2016 \text { ) } \\
21 \mathrm{~h} \text { for all configurations } \\
\text { except AC-coupled retrofit, } \\
\text { which has higher assumed PII } \\
\text { labor requirements ( } 39 \mathrm{~h} \text { ) due } \\
\text { to need for two separate PII } \\
\text { processes. }\end{array}$ & $\begin{array}{l}\text { Includes assumed building permitting and } \\
\text { interconnection application fees of } \$ 600 \\
\text { and non-electrician staff hours for building- } \\
\text { permit preparation and submission, } \\
\text { interconnection application preparation and } \\
\text { submission, and travel time to and from the } \\
\text { site for all required inspections. }\end{array}$ \\
\hline $\begin{array}{l}\text { Installation labor } \\
\text { (burdened) }\end{array}$ & $\begin{array}{l}\text { Electrician labor: } \$ 51.15 / \mathrm{h} \\
\text { Non-electrician labor: } \\
\$ 30.43 / \mathrm{h} \text { (BLS 2016) } \\
\text { Assumes higher installation } \\
\text { requirements for large-battery } \\
\text { systems due to need to re- } \\
\text { wire main panel. }\end{array}$ & $\begin{array}{l}\text { Includes direct-labor costs based on hourly } \\
\text { wage rates from Bureau of Labor Statistics } \\
\text { plus workers' compensation, state and } \\
\text { federal unemployment insurance, } \\
\text { compliance with Federal Insurance } \\
\text { Contributions Act (FICA), and public liability } \\
\text { insurance. } \\
\text { Includes labor costs of travel time to and } \\
\text { from the customer site, equipment loading } \\
\text { and unloading, and onsite labor for all } \\
\text { equipment installation and wiring. }\end{array}$ \\
\hline Sales tax & $6.74 \%$ & $\begin{array}{l}\text { National average sales tax rate on } \\
\text { equipment (RSMeans 2015) }\end{array}$ \\
\hline $\begin{array}{l}\text { Supply-chain } \\
\text { costs (\% of } \\
\text { hardware costs) }\end{array}$ & $5 \%$ & $\begin{array}{l}\text { Includes costs of inventory, shipping, and } \\
\text { handling of equipment. }\end{array}$ \\
\hline Electrical BOS & $\begin{array}{l}\text { Small-Battery Case } \\
\text { - } \quad \$ 2,731 \text { (DC-coupled) } \\
\text { - } \quad \$ 2,413 \text { (AC-coupled) } \\
\text { - } \quad \$ 2,681 \text { (AC-coupled } \\
\quad \text { retrofit) } \\
\text { Large-Battery Case } \\
\text { - } \quad \$ 5,463 \text { (DC-coupled) } \\
\text { - } \quad \$ 4,826 \text { (AC-coupled) } \\
\text { Assumes higher electrical } \\
\text { BOS costs for DC-coupled } \\
\text { systems due to need for } \\
\text { charge controller }\end{array}$ & $\begin{array}{l}\text { Ex-factory gate prices for conductors, } \\
\text { switches, combiners, and transition boxes, } \\
\text { as well as conduit, grounding equipment, } \\
\text { monitoring system or production meters, } \\
\text { fuses, and breakers. }\end{array}$ \\
\hline Structural BOS & $\$ 651$ & $\begin{array}{l}\text { Ex-factory gate prices; }{ }^{22} \text { includes flashing } \\
\text { for roof penetrations and all battery- } \\
\text { mounting hardware. }\end{array}$ \\
\hline
\end{tabular}
${ }^{22}$ The first buyers of hardware ex-factory gate can be developers, EPC contractors, installers, distributors, retailers,
or other end users. 


\begin{tabular}{|l|l|l|}
\hline Category & Modeled Value & Description \\
\hline $\begin{array}{l}\text { Battery-based } \\
\text { inverter }\end{array}$ & $\$ 0.59 / \mathrm{W}$ & $\begin{array}{l}\text { Ex-factory gate prices (first buyer) ASP, } \\
\text { Tier 1 inverters }\end{array}$ \\
\hline PV inverter & $\begin{array}{l}\text { Single-phase } \\
\text { string inverter: } \$ 0.15 / \mathrm{Wdc}\end{array}$ & $\begin{array}{l}\text { Ex-factory gate prices (first buyer) ASP, } \\
\text { Tier 1 inverters }\end{array}$ \\
\hline $\begin{array}{l}\text { Lithium-ion } \\
\text { battery }\end{array}$ & $\begin{array}{l}\$ 3,0003-\mathrm{kW} / 6-\mathrm{kWh} \\
\$ 10,0005-\mathrm{kW} / 20-\mathrm{kWh}\end{array}$ & $\begin{array}{l}\text { Ex-factory gate prices (first buyer) ASP, } \\
\text { Tier 1 supplier }\end{array}$ \\
\hline PV module & $\$ 0.64 / \mathrm{Wdc}$ & $\begin{array}{l}\text { Ex-factory gate prices (first buyer) ASP, } \\
\text { Tier 1 modules }\end{array}$ \\
\hline
\end{tabular}

\section{Other Barriers to Residential PV-Plus-Storage Systems}

As noted in Section 2, energy storage deployment has been impeded by value and cost barriers. Our detailed cost modeling helps quantify the cost barriers and suggests areas where costreduction efforts are most needed. We performed this modeling based on our understanding of current component costs and industry and regulatory practices, which were informed by our stakeholder interviews and other sources. This same research also revealed insights into cost and value barriers beyond what we captured in our modeling. For example, by blurring the lines between a generation and consumption resource, energy storage has challenged the policy community to develop regulations allowing storage owners to realize value across traditionally separate levels of the energy value chain. Further, authorities having jurisdiction (AHJs) are often unfamiliar with energy storage devices, giving rise to new questions around permitting and safety. These factors have resulted in significant regulatory uncertainty in the energy storage industry, which is consistently cited as one of the primary barriers to increasing energy storage deployment (Sioshansi et al. 2012, Bhatnagar et al. 2013, Stein 2014). This section discusses barriers related to permitting (Section 7.1), interconnection and NEM (7.2), benefit valuation (7.3), incentives (7.4), and utility rates (7.5).

\subsection{Permitting}

Obtaining permission to install and operate an energy storage device can be a complicated, expensive, and uncertain process in many jurisdictions. Our benchmarking results suggest that permitting, inspection, and interconnection (PII) costs add between $\$ 700$ and $\$ 1,200$ to the installed price of a standalone PV system, depending on the configuration. However, modeled PII costs based on installed systems may not sufficiently capture the extent to which inconsistent permitting requirements impede storage deployment. In a recent survey of 11 energy storage investors, permitting is cited as a significant barrier for deployment of storage systems (CUNY 2015). Survey respondents cited permitting challenges as more important contributors to installed costs than interconnection, financing, and other regulatory challenges (CUNY 2015). In some jurisdictions, there is a need to obtain approval from multiple AHJs, submit extensive documentation, and complete more inspections than typically required for standalone PV systems (CUNY 2015). Table 3 summarizes a sample of the various storage-related permits that might be required for a PV-plus-storage system. The permitting burden is due in part to the lack of cohesive industry-accepted codes, standards, and best practices. Further, as with standalone 
PV systems, storage permitting requirements vary considerably across AHJs and across states. Our interviews indicate persistent challenges with local permitting of PV-plus-storage systems, because timelines and costs differ across AHJs and often reflect a lack of local familiarity with such systems. Several industry stakeholders reported the need to educate permitting officials about storage technology during the permitting process. The pervasive unfamiliarity with storage introduces additional regulatory uncertainty and poses a barrier to widespread PV-plus-storage growth. $^{23}$

\section{Table 3. Example PV-Plus-Storage Permitting Considerations}

\begin{tabular}{|c|c|}
\hline Permit & Description \\
\hline Building & $\begin{array}{l}\text { Storage installations may need to comply with various building codes, including } \\
\text { materials-acceptance codes that dictate which materials may be stored in } \\
\text { buildings and in what quantities (CUNY 2015). } \\
\text { In addition to standard permitting requirements, many jurisdictions impose weight } \\
\text { limits on wall mountings. One installer estimated that having to affix a battery } \\
\text { system to the concrete of a garage versus wall mounting the system could add } \\
\$ 300-\$ 400 \text { to the system cost. } \\
\text { Some jurisdictions require garage-installed storage systems to be protected from } \\
\text { vehicles by floor-mounted bollards, adding an estimated } \$ 150 \text { in costs, despite } \\
\text { lack of requirements in the National Electrical Code for vehicle protection. }\end{array}$ \\
\hline Construction & $\begin{array}{l}\text { Certain storage installations that require significant structural changes may } \\
\text { require a construction permit. Storage installations in buildings with asbestos may } \\
\text { require additional permits. }\end{array}$ \\
\hline Electrical & $\begin{array}{l}\text { Electrical permits may be required. For example, all storage installations in New } \\
\text { York City require an electrical permit, and certain systems require approval from } \\
\text { the City's Electrical Advisory Board. }\end{array}$ \\
\hline Fire & $\begin{array}{l}\text { Review of battery systems by fire departments adds additional time to the } \\
\text { permitting process, given the relative unfamiliarity of many fire departments with } \\
\text { battery systems and potential safety concerns. For example, the New York City } \\
\text { Fire Department has only developed guidance for lead-acid batteries, and it has } \\
\text { prohibited lithium-ion systems inside buildings in New York City altogether } \\
\text { pending further analysis. Section } 608 \text { of the International Fire Code provides fire } \\
\text { safety requirement guidance for stationary storage-battery systems. }\end{array}$ \\
\hline
\end{tabular}

As an example of the potentially onerous and complex permitting experience, Figure 8 illustrates the permitting process for an energy storage device based on findings compiled by CUNY (2015). This process reflects the additional complexities involved in safely permitting storage systems in densely populated urban areas.

\footnotetext{
${ }^{23}$ California recently introduced legislation that would require AHJs to adopt standardized storage permitting guidelines and fee structures, as was done for PV permitting in 2014 (California Legislative Information 2016 , Kaatz and Anders 2015).
} 


\section{Fire Department}

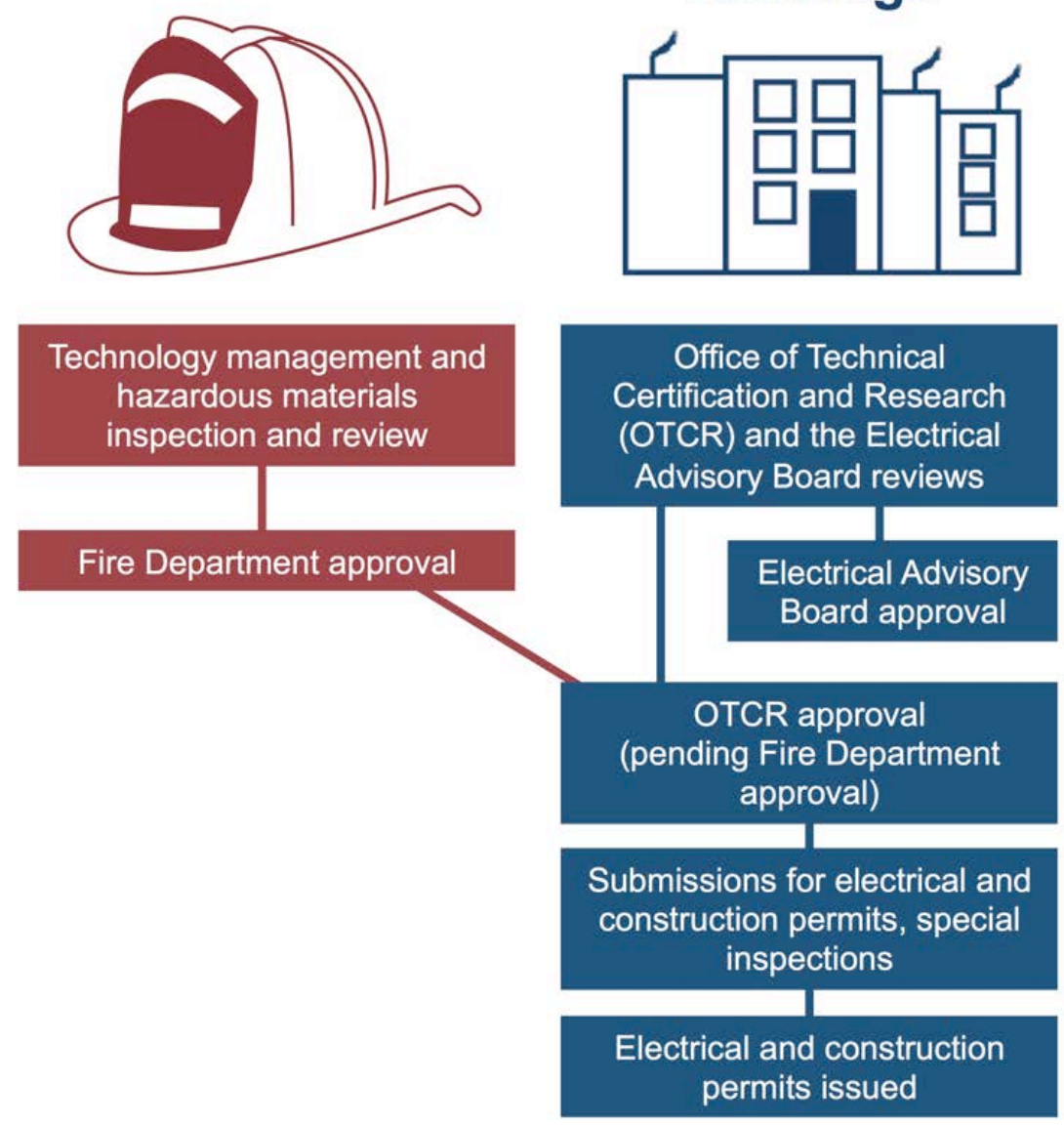

Department of Buildings

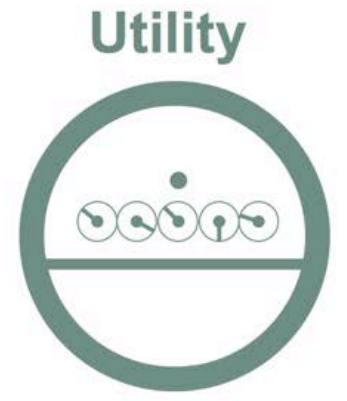
utility review

(OTCR) and the Electrical

Advisory Board reviews

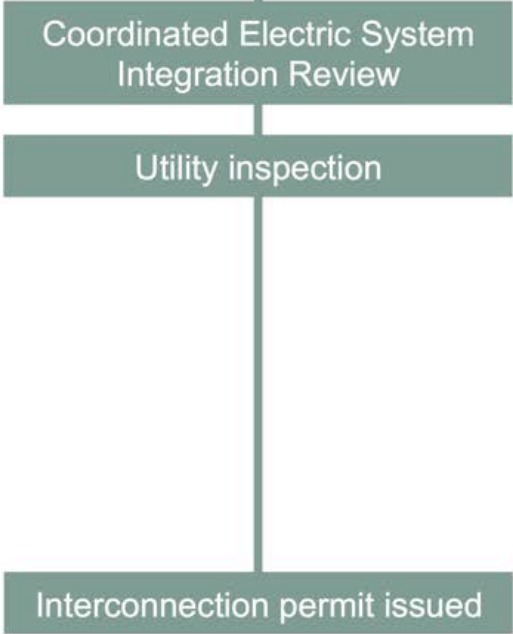

Figure 8. Schematic of energy storage permitting process in New York City, based on CUNY (2015)

\subsection{Interconnection and Net Metering}

The complexity of PV-plus-storage systems has resulted in a variety of interconnection- and NEM-related barriers, which — compared with standalone PV processes-generally add cost to system installation, reduce the value of the system, or both. For example, California and New York both have additional interconnection procedures for the storage component of a PV-plusstorage system, rather than allowing it simply to be added to a standalone PV interconnection application; and both include safeguards against using batteries to generate revenue by arbitraging grid electricity via NEM and time-of-use rates.

In California, energy storage devices are not treated as generators when paired with an NEMeligible PV system, under certain size restrictions. ${ }^{24}$ PV-plus-storage systems, including retrofits, require an interconnection agreement for the energy storage device (standalone energy storage systems must follow a separate procedure). Different requirements depend on the inverter rating of the storage system (Table 4). For systems less than $10 \mathrm{~kW}$, an estimation method is used to

\footnotetext{
${ }^{24}$ The interconnection requirements listed here are based on the Southern California Edison and Pacific Gas \& Electric service territories. Slight differences may exist between the two utilities.
} 
validate NEM credits. Most residential systems will fall under this category. In contrast, systems larger than $10 \mathrm{~kW}$ must install either a non-export relay device on the storage device or a netgeneration output meter (NGOM) on the PV system. The non-export relay device prevents the system owner from exporting energy from the battery to the grid. The NGOM tracks the output of the PV system before the electricity enters the battery or grid. Both devices help regulators prevent system owners from recycling grid electricity through the battery and back onto the grid for NEM purposes. In both cases, the regulations are designed to prevent the use of the battery for arbitraging grid electricity via time-of-use rates. This approach does not necessarily maximize the value of the system to the grid and/or system owner.

Table 4. Interconnection Requirements by Storage Device Size in California

\begin{tabular}{|l|l|l|}
\cline { 2 - 3 } \multicolumn{1}{c|}{} & $\begin{array}{c}\text { Storage Device Inverter Rating } \\
<10 \mathbf{~ k W}\end{array}$ & $\begin{array}{c}\text { Storage Device Inverter Rating } \\
>10 \mathrm{~kW}\end{array}$ \\
\hline Size restrictions & None & $\begin{array}{l}\text { Storage device capacity cannot } \\
\text { exceed 150\% of the power } \\
\text { capacity of the PV system }\end{array}$ \\
\hline Metering requirements & $\begin{array}{l}\text { None; an estimation method is } \\
\text { used to validate NEM credits }\end{array}$ & $\begin{array}{l}\text { Customer must install a non- } \\
\text { export relay on the storage } \\
\text { device or an NGOM on the PV } \\
\text { system }\end{array}$ \\
\hline
\end{tabular}

In contrast, storage devices are treated as generators when coupled with PV in New York under the state's Standardized Interconnection Requirements (CUNY 2015). PV-plus-storage system owners must file separate interconnection applications for the PV and storage systems (CUNY 2015). System owners may begin interconnection procedures in parallel with other permitting procedures. Although PV systems smaller than $25 \mathrm{~kW}$ do not require an onsite utility inspection, all storage devices must complete onsite utility inspections. PV-plus-storage system owners are eligible for NEM from the PV system if the system design meets one of the following conditions:

1. The PV system and the storage device are not electrically separated (connected behind two separate meters).

2. The storage device is configured to shut off whenever the PV system begins exporting to the grid.

3. The system is configured such that the storage device cannot draw power from the grid.

4. The system is configured such that the storage device is only used during grid outages.

Of the above conditions, only conditions \#2 and \#3 are suitable for a PV-plus-storage application designed primarily to increase PV self-consumption. 


\subsection{Benefit Valuation}

In addition to increasing PV self-consumption, allowing for back-up power in the event of a grid outage, and reducing residential demand charges, ${ }^{25}$ distributed energy storage could also be used to provide a number of grid-level benefits such as voltage and frequency regulation, deferred infrastructure investment, and resource adequacy. New business models that aggregate and coordinate a fleet of networked residential PV-plus-storage assets could provide these grid-level benefits. However, these value streams are difficult to realize due to current market and regulatory constraints. To the extent that these additional value streams could improve the economics of residential-scale PV-plus-storage, the undervaluation of energy storage at the grid level poses a barrier to PV-plus-storage deployment.

Energy storage undervaluation stems in part from existing market structures that were not designed for energy storage and distributed energy resource aggregation. In U.S. deregulated electricity markets, generation, capacity, and ancillary services are bought and sold on wholesale markets, whereas transmission and distribution services are generally rate-based. Energy storage can technically provide several of these services, but current regulatory structures typically require prospective storage aggregators and/or utilities to make a mutually exclusive choice between selling generation services into wholesale markets or rate-basing energy storage investments to provide transmission services (Sioshansi et al. 2012, Bhatnagar et al. 2013, Stein 2014). This structure prevents prospective aggregators from realizing the full potential value of aggregated energy storage devices (and passing this value onto residential customers).

A series of recent Federal Energy Regulatory Commission (FERC) orders has begun to lay a framework for improved storage valuation. FERC 890-2007 amended the ancillary services schedule to allow non-generation resources to provide ancillary services. FERC 755 (2011) increased payments to fast-responding resources, including batteries that bid into frequencyregulation markets. In a Notice of Proposed Rulemaking preceding FERC 784, FERC noted that it was open to considering storage assets spanning multiple service classifications (e.g., generation and transmission) on a case-by-case basis. In November 2016, FERC proposed an additional rule that would require regional transmission organizations/independent system operators to create regulations that accommodate the "physical and operational characteristics" of energy storage devices. These developments could ultimately allow residential customers to realize additional value streams from PV-plus-storage, thereby improving the overall economics for individual systems.

\subsection{Incentives}

The federal government and several states have introduced or are in the process of introducing incentives applicable to PV-plus-storage, often at the commercial and utility scale. The design of some incentives, however, can present a barrier to obtaining the incentives, realizing the full value of energy storage systems that receive the incentives, or both.

At the federal level, the U.S. Internal Revenue Service (IRS) determined in a Private Letter Ruling that storage devices used in PV-plus-storage applications are eligible for up to a 30\% tax

\footnotetext{
${ }^{25}$ Although commercial utility rate structures most often include some form of demand charge, as of June 29, 2016, less than 10 utilities have established mandatory demand charges for residential customers, with 28 investor-owned utilities offering at least one tariff with voluntary residential demand charges (GTM 2016c).
} 
credit under the federal solar ITC (IRS 2013). The amount of the ITC is prorated according to the system's solar utilization rate, which is the percentage of stored electricity derived from solar power over a given period. ${ }^{26}$ For example, if a system's solar utilization rate is $90 \%$ in the first year (i.e., $90 \%$ of stored electricity is derived from solar power), then the system owner is eligible for a $27 \%$ tax credit. If solar utilization falls below $75 \%$ in the first year, then the system owner is no longer eligible for the ITC (sometimes referred to as the " $75 \%$ cliff"). Parts of the ITC are subject to recapture by the IRS if solar utilization falls below the rate set in year 1. For example, if a system's solar utilization rate is set in year 1 at $90 \%$, but falls to $80 \%$ in subsequent years (up to year 5), the IRS may recapture $3 \%$ of the claimed ITC. This provision is meant to ensure that the storage is used primarily to store PV-generated electricity, not grid electricity. This constraint on system design and operation creates uncertainty about the actual incentive available to a given system while limiting the value an owner might obtain. Legislation recently introduced in the U.S. House of Representatives (H.R.5350, Energy Storage Act of 2016) and Senate (S.3159, Energy Storage Tax Incentive and Deployment Act of 2016) seeks to clarify the tax code and make all grid-tied storage systems eligible for the $30 \%$ ITC. In the absence of clarifying actions from Congress, or the IRS, developers may need to seek tax guidance on individual projects.

Several states have developed incentive programs for non-residential behind-the-meter energy storage (e.g., Connecticut Microgrid Program, Massachusetts Community Clean Energy Resiliency Initiative, New Jersey Renewable Electric Storage Program), whereas relatively fewer incentives have emerged for residential customers. In 2016, a bill was introduced in Hawaii that would have provided energy storage rebates to low- to moderate-income households. Although it was not passed in the May legislative session, the bill is expected to be taken up again in 2017 (Maloney 2016). Five years prior, in 2011, the California Public Utilities Commission (CPUC) amended the eligibility criteria for the California Self-Generation Incentive Program (SGIP) to include advanced energy storage. ${ }^{27}$ However, relative to the commercial and industrial market segments, very few residential storage installations have been installed under the SGIP to date. ${ }^{28}$ To help increase residential participation, in 2016, the CPUC further amended the SGIP to reserve $15 \%$ of the program's total storage allocation for projects less than $10 \mathrm{~kW}$, resulting in about $\$ 9.3$ million annually for residential storage from 2017 through 2019. Further changes include making incentives available throughout the year, rather than on a first-come, first-served basis, and replacing the dollars-per-watt $(\$ / \mathrm{W})$ incentive with a dollars-per-watt-hour $(\$ / \mathrm{Wh})$ incentive that steps down from $\$ 0.60 / \mathrm{Wh}$ to $\$ 0.40 / \mathrm{Wh}$ for storage less than $10 \mathrm{~kW}$ (CPUC 2016b).

California and Oregon have passed energy storage mandates that could stimulate investment in residential-scale PV-plus-storage systems. California's investor-owned utilities (IOUs) are required to procure a total of 1,825 $\mathrm{MW}$ of energy storage under two separate mandates, including $500 \mathrm{MW}$ targeted toward distributed energy storage. Oregon's mandate requires the state's two IOUs to install a minimum of 5 MWh of energy storage capacity by 2020 . Massachusetts has proposed an energy storage mandate of 600 MW by 2025.

\footnotetext{
26 "Solar utilization rate" is a term applied in this report for simplicity. It is not a technical term used by the IRS.

${ }^{27}$ By October 2016, more than 600 advanced energy storage projects with over $8 \mathrm{MW}$ of capacity had received SGIP incentives (CPUC 2016a).

${ }^{28}$ Residential storage installers often cite application complexity and first-come, first-served program design as reasons for limited participation in the SGIP to date, relative to the commercial and industrial market segments.
} 
In 2016, the Vermont utility Green Mountain Power began offering incentives for residential energy storage. The program offered residential customers the opportunity to lease a Tesla home battery for $\$ 37.50 /$ month. Customers that choose to buy the system can earn bill credits of $\$ 31.76 /$ month for allowing Green Mountain Power to access the battery.

\subsection{Utility Rates}

In general, flat electricity rates reduce the potential value from load shifting provided by residential PV-plus-storage systems, notably when NEM is available, because there is no incentive to shift excess PV generation from one time of day to another. Many of those interviewed for this report believe that properly designed, mandatory residential time-of-use rates (as in California) could improve the load-shifting value proposition for PV-plus-storage systems. PV tariff design can also have direct implications for PV-plus-storage. For example, by eliminating NEM for new PV customers, Hawaii's recently adopted "self-supply" tariff discourages standalone PV while incentivizing the use of storage to maximize PV selfconsumption. A forthcoming NREL report will examine various rate structures across the United States and the potential value from load shifting provided by residential PV-plus-storage.

\section{Conclusion}

This report fills a gap in the existing knowledge about PV-plus-storage system costs, prices, and value by providing detailed component cost and system price benchmarks for residential PVplus-storage systems. As summarized in Table 5, our modeling suggests that the price of a typical, new PV-plus-storage system (5.6-kW PV array, 3-kW/6-kWh lithium-ion battery system) built for PV self-consumption and back-up of limited, critical loads in the event of a grid outage is about twice as high as the price of a standalone $5.6-\mathrm{kW}$ PV system. Increasing the battery system size to enable PV self-consumption and greater back-up power capability (5.6-kW $\mathrm{PV}$ array, $5-\mathrm{kW} / 20-\mathrm{kWh}$ lithium-ion battery system) increases the price of a typical system by about two thirds, owing to larger battery-sizing requirements and associated costs.

The price of new small-battery systems built with AC coupling is $6.7 \%$ ( $\$ 29,568$ vs. $\$ 27,703)$ higher than the price of those built with DC coupling, mainly because of hardware and labor costs associated with the additional grid-tied inverter. However, installed price is not the only consideration when comparing AC- and DC-coupled systems: AC-coupled systems are more efficient in applications where PV energy is generally used at the time of generation, and DCcoupled systems are more efficient in applications where PV energy is stored and used later. Technological changes could alter these characteristics in the future.

The price of a retrofitted small-battery AC-coupled system (with the storage added to an existing $\mathrm{PV}$ array) is about $11 \%$ higher than the price of a new system (with the storage and PV installed simultaneously). The simultaneous installation produces installation labor, wiring, and regulatory cost savings. We do not model the price of adding a DC-coupled battery to an existing PV system, because this configuration presents several cost and regulatory challenges and is not commonly deployed. 
Table 5. Summary of Modeled PV and PV-Plus-Storage Installed Price Benchmarks

\begin{tabular}{|l|c|c|}
\cline { 2 - 3 } \multicolumn{1}{c|}{} & \multicolumn{2}{c|}{ Price (2016 U.S. dollars) } \\
\hline System Design & DC-Coupled & AC-Coupled \\
\hline PV only (5.6 kW) & \multicolumn{2}{|c|}{$\$ 15,581$} \\
\hline New PV-plus-storage, small-battery (3-kW/6-kWh) case & $\$ 27,703$ & $\$ 29,568$ \\
\hline Retrofit PV-plus-storage, small-battery (3-kW/6-kWh) case & - & $\$ 32,786$ \\
\hline New PV-plus-storage, large-battery (5-kW/20-kWh) case & $\$ 45,237$ & $\$ 47,171$ \\
\hline
\end{tabular}

For new systems, the storage and PV components are installed simultaneously. For retrofit systems, the storage is added later to an existing PV array.

Hardware costs constitute about half the total price of our modeled small-battery systems. The largest single hardware cost for these systems is the battery-based inverter $(\$ 3,596)$, followed by the PV array $(\$ 3,584)$ and the lithium-ion battery $(\$ 3,000)$. For our large-battery systems, hardware costs constitute about $60 \%$ of the total price, with the $\$ 10,000$ battery dominating the hardware cost contribution, followed by electrical BOS $(\$ 4,826-\$ 5,463)$ and the $8-\mathrm{kW}$ batterybased inverter $(\$ 4,795)$. The ranking of soft cost contributions varies by system configuration/application, with major contributions for all systems from net profit, sales and marketing, and installation labor.

Our modeling helps quantify the component cost and system price barriers to deployment of PVplus-storage. We also examine cost and value barriers beyond what we captured in the modeling, including those related to complex and inconsistent permitting processes, time-consuming and restrictive interconnection and NEM requirements, inadequate valuation of storage's benefits, constrained government incentives, and flat utility rates. As we continue to benchmark PV-plusstorage component costs and system prices, we will incorporate insights into these barriers to refine our modeling while building a better understanding of the value barriers to deployment.

Finally, future work will include a more comprehensive approach to analyzing the combination of PV and storage, moving beyond electrical battery storage alone to consider a wide range of options that enable energy storage and dispatch, such as domestic water heaters and controllable heating, ventilation, and air-conditioning systems. This future work will build on our battery component cost and system price benchmarking by studying how existing cost structures for batteries affect their economic potential under various utility rate structures and how batteries compete with other relatively low-cost, but less-flexible, PV-coupled energy storage options. The long-term objective of this body of research is to understand how distributed energy storage innovations - both electrical battery storage and other forms - may interact with and enhance PV value. 


\section{Glossary}

AC coupling

Application

Charge controller

Configuration

DC coupling

Depth of discharge

Resiliency

Soft cost
PV-plus-storage system configuration characterized by use of a gridtied inverter to feed PV output directly to the customer's load or the grid. PV electricity is first converted (DC to AC) through the grid-tied inverter, and then electricity that is not immediately consumed or fed to the grid is converted (AC to DC) through a battery-based inverter to charge a battery.

The particular use of a PV-plus-storage system, which influences the optimal configuration of the system. For example, a system might be configured for a consumption application in which the customer more frequently consumes PV output directly at the time of generation, or it might be configured as a storage application in which the customer more frequently stores PV output in the battery for later use.

A device used in DC-coupled PV-plus-storage systems to step down the PV output voltage to a level that is safe for the battery.

The characteristics that determine a PV-plus-storage system's functionality, including PV system capacity, battery energy capacity, battery power capacity, and whether the battery is DC or AC coupled.

PV-plus-storage system configuration characterized by transmission of DC electricity from the PV array to the battery or a battery-based inverter. PV output and the battery's stored electricity are converted (DC to AC) by the battery-based inverter to serve customer load or for export to the grid. A DC-coupled system often requires a charge controller to step down the PV output voltage to a level that is safe for the battery.

The proportion of a battery's energy capacity that may be discharged to supply electricity. For example, an $80 \%$ depth of discharge means $80 \%$ of a battery's nominal energy capacity may be discharged.

The ability of a storage system to provide relatively long periods of back-up power during grid outages.

Non-hardware cost component, such as the costs related to customer acquisition, permitting, inspection, and interconnection. 


\section{References}

Ardani, K., G. Barbose, R. Margolis, R. Wiser, D. Feldman, and S. Ong. 2012. Benchmarking Non-Hardware Balance of System (Soft) Costs for U.S. Photovoltaic Systems Using a DataDriven Analysis from PV Installer Survey Results. NREL/TP-7A20-56806. Golden, CO: National Renewable Energy Laboratory.

Bhatnagar, D., A. Currier, J. Hernandez, O. Ma, and B. Kirby. 2013. Market and Policy Barriers to Energy Storage Deployment. SAND2013-7606, Albequerque: Sandia National Laboratories.

BLS (U.S. Bureau of Labor Statistics). 2016. "Occupational Employment Statistics." Accessed May 2016. http://www.bls.gov/oes/tables.htm.

BNEF (Bloomberg New Energy Finance). 2016. "Cost Reductions and Residential Energy Storage Drivers.” Energy Smart Technologies: Research Note, January 29.

Butler, P., J. Iannucci, J. Eyer. 2003. Innovative Business Cases for Energy Storage in Restructured Electricity Marketplace. SAND2003-0362. February 2003.

California Legislative Information. 2016. “AB-2713 Land Use: Local Ordinances: Energy Systems." Accessed September 2016. http://leginfo.legislature.ca.gov/faces/billTextClient.xhtml?bill id=201520160AB2713.

CEC (California Energy Commission). 2016. "Inverter Performance Test Summaries.” Accessed October 2016. http://www.gosolarcalifornia.ca.gov/equipment/inverter_tests/summaries/.

Chang, J., J. Pfeifenberger, K. Spees, M. Davis, I. Karkatsouli, L. Regan, and J. Mashal. 2014. The Value of Distributed Electricity Storage in Texas. Cambridge, MA: Brattle Group.

Chung, D., C. Davidson, R. Fu, K. Ardani, and R. Margolis. 2015. U.S. Photovoltaic Prices and Cost Breakdowns: Q1 2015 Benchmarks for Residential, Commercial, and Utility-Scale Systems. NREL/TP-6A20-64746. Golden, CO: National Renewable Energy Laboratory.

Clean Energy Group. 2016. "Financing Solar + Storage with Federal Tax Credits. Resilient Power Project." Accessed September 2016. http://www.cleanegroup.org/wpcontent/uploads/Webinar-Slides-2.3.2016.pdf.

CPUC (California Public Utilities Commission). 2016a. "SGIP Weekly Projects Report." Accessed October 2016. http://www.cpuc.ca.gov/sgip/.

CPUC (California Public Utilities Commission). 2016b. "Decision Revising the Self-Generation Incentive Program Pursuant to Senate Bill 861, Assembly Bill 1478, and Implementing Other Changes. Rulemaking 12-11-005.” Accessed October 2016. http://docs.cpuc.ca.gov/PublishedDocs/Published/G000/M163/K870/163870439.pdf.

CPUC (California Public Utilities Commission). 2013. "Order Instituting Rulemaking Pursuant to Assembly Bill 2514." Accessed September 2016. http://docs.cpuc.ca.gov/PublishedDocs/Efile/G000/M065/K706/65706057.PDF. 
CUNY (City University of New York). 2015. The Energy Storage Systems Permitting and Interconnection Process Guide for New York City. New York: City University of New York.

CUNY (City University of New York). 2016. Resilient PV Retrofit and Storage Ready Guidelines. NY Solar Mart DG Hub. New York: City University of New York.

Deloitte. 2015. Energy Storage: Tracking the Technologies that Will Transform the Power Sector. New York: Deloitte.

Denholm, P., B. Kirby, O. Ma, and M. O'Malley. 2013. The Value of Energy Storage for Grid Applications. NREL/TP-6A20-58465. Golden, CO: National Renewable Energy Laboratory.

Ecofys. 2014. Energy Storage Opportunities and Challenges. Utrecht, The Netherlands: Ecofys.

EuPd Research and Green Tech Media. 2016. "PV Installer Survey USA 2015/16.” Accessed October 2016. https://www.greentechmedia.com/articles/read/batteries-still-cant-giveconsumers-what-they-expect-for-backup-power.

Fitzgerald, G., J. Mandel, J. Morris, and H. Touati. 2015. The Economics of Battery Storage: How Multi-Use, Customer Sited Batteries Deliver the Most Services and Value to Customers on the Grid. Snowmass, CO: Rocky Mountain Institute.

Fu, R., D. Chung, T. Lowder, D. Feldman, K. Ardani, and R. Margolis. 2016. U.S. Solar Photovoltaic System Cost Benchmark: Q1 2016. NREL/TP-6A20-66532. Golden, CO: NREL.

Goodrich, A., T. James, and M. Woodhouse. 2012. Residential, Commercial, and Utility-Scale Photovoltaic System Prices in the United States: Current Drivers and Cost Reduction Opportunities. NREL/TP-6A20-53347. Golden, CO: National Renewable Energy Laboratory.

GTM (GreenTech Media Research). 2016a. U.S. Energy Storage Monitor Q2 2016. Boston: GTM.

GTM (GreenTech Media Research). 2016b. "Here's Everything New about Tesla's Updated Power Wall.” Energy Storage, November 7, 2016.

GTM (GreenTech Media Research). 2016c. "State Bulletin: Are Residential Demand Charges Becoming a Trend in the US?" EQ Research and GTM Squared, June 29, 2016.

IRS (U.S. Internal Revenue Service). 2013. Private Letter Ruling 201308005. Washington, DC: IRS. https://www.irs.gov/pub/irs-wd/1308005.pdf.

Jaffe, S. 2016. Balance of Systems Economics and Functions. Boulder: Carin ERA.

Kaatz, J., and S.J. Anders. 2015. AB 2188: Implementation of the Solar Rights Act at the Local Level. San Diego: Center for Sustainable

Energy. https://energycenter.org/sites/default/files/docs/nav/policy/research-andreports/AB_2188_Implementation_Guide.pdf. 
Lazard. 2015. Lazard's Levelized Cost of Storage Analysis Version 1.0. New York: Lazard.

Maloney, P. 2016. "Energy Storage Bills Fail in Hawaii, but Could Re-Appear in Next Legislative Session." UtilityDive, May 17, 2016.

Manghani, R. 2014. The Future of Solar-Plus-Storage in the U.S. Boston: GTM Research.

Pierre-Olivier, M., and R. Claude. 2010. "Partial AC-coupling in Minigrids." In $5^{\text {th }}$ European Conference PV-Hybrid and Mini-Grid, Tarragona, Spain, 2010.

RSMeans, ed. 2015. RSMeans Building Construction Cost Data 2015, 73 ${ }^{\text {rd }}$ annual edition. Norwell, MA: RSMeans.

Ryhd, C.J., and B. Sanden. 2005. "Energy Analysis of Batteries in Photovoltaic Systems. Part II: Energy Return Factors and Overall Battery Efficiencies." Energy Conversion and Management 46: $1980-2000$.

Sioshansi, R., P. Denholm, and T. Jenkin. 2012. "Market and Policy Barriers to Deployment of Energy Storage." Economics of Energy and Environmental Policy 1(2): 47-63.

Stein, A. 2014. "Reconsidering Regulatory Uncertainty: Making a Case for Energy Storage." Florida State University Law Review 41: 697-766.

Walawalkar, R., J. Apt, and R. Mancini. 2007. "Economics of Electric Energy Storage for Energy Arbitrage and Regulation in New York." Energy Policy 35: 2558-2568. 


\section{Appendix A: NREL-RMI Interview Questions Used for Data Collection}

Please answer the following questions about the company or organization you represent. Company Name:

Primary Contact First and Last Name:

Primary Contact Email Address:

Primary Contact Phone:

1) How does your company perceive distributed PV plus storage technology, its applications, challenges and opportunities?

2) What kinds of studies and analysis is your company or organization conducting to better understand the technology?

3) If your company is actively involved with installing PV plus storage systems, how many total installations did your company complete in 2015? 2016?

4) What are the most common configurations for distributed PV plus storage installations?

5) What are the key considerations related to AC coupling vs DC coupling and the intended end use of the battery paired with PV?

6) What are the most prominent applications for PV plus storage installations in today's market? How do you anticipate that is likely to change over the next 5 year? 10 years?

7) Based on your experience, are there any regulatory or non-technology challenges associated with PV plus storage deployment at the residential scale? At the commercial scale?

8) Are there certain locations where it is more difficult to permit and interconnect than others? If so, please describe.

9) Relative to a typical residential PV system, is there more labor hours required for installation when pairing the PV system with a battery? If so, how many?

10) For a typical PV plus storage installation, what are the component requirements, hardware, and non-hardware costs? How does this vary by application and configuration? 


\section{Appendix B: Tabular Modeling Results}

Table B-1 and Table B-2 provide tabular values for the results shown in Figure 6 and Figure 7 (in Section 6), respectively.

Table B-1. Itemized Cost and Price Components for Residential PV-Plus-Storage Systems, SmallBattery Case (2016 U.S. Dollars)

\begin{tabular}{|c|c|c|c|c|}
\hline \multirow[b]{2}{*}{ Cost and Price Components } & \multirow[b]{2}{*}{$\begin{array}{c}\text { PV Only } \\
5.6 \mathrm{~kW} \\
(\$)\end{array}$} & \multicolumn{2}{|c|}{$\begin{array}{l}\text { PV and Battery Installed } \\
\text { Simultaneously }\end{array}$} & \multirow{2}{*}{$\begin{array}{c}\text { Battery } \\
\text { Added to } \\
\text { Existing PV } \\
\text { Array } \\
\text { PV (5.6 kW) } \\
+ \text { Storage } \\
\text { AC-coupled } \\
3 \mathrm{~kW}, 6 \mathrm{kWh} \\
(\$) \\
\end{array}$} \\
\hline & & $\begin{array}{c}\text { PV (5.6 kW) } \\
+ \text { Storage } \\
\text { DC-coupled } \\
3 \mathrm{~kW}, 6 \mathrm{kWh} \\
\text { (\$) }\end{array}$ & $\begin{array}{c}\text { PV (5.6 kW) } \\
+ \text { Storage } \\
\text { AC-coupled } \\
3 \mathrm{~kW}, 6 \mathrm{kWh} \\
(\$)\end{array}$ & \\
\hline PV modules & 3,584 & 3,584 & 3,584 & 3,584 \\
\hline Lithium-ion battery & - & 3,000 & 3,000 & 3,000 \\
\hline Inverter (grid-tied + bi-directional) & 857 & 3,596 & 4,453 & 4,453 \\
\hline Structural BOS & 651 & 651 & 651 & 651 \\
\hline Electrical BOS & 1,072 & 2,731 & 2,413 & 2,681 \\
\hline Supply-chain costs & 966 & 678 & 705 & 1,419 \\
\hline Sales tax & 415 & 914 & 950 & 1,026 \\
\hline Install labor (burdened) & 1,731 & 2,773 & 3,188 & 4,074 \\
\hline Permitting, inspection, interconnection & 549 & 1,253 & 1,253 & 1,802 \\
\hline Overhead (general \& admin.) & 1,848 & 1,848 & 1,848 & 2,148 \\
\hline $\begin{array}{l}\text { Sales \& marketing (customer } \\
\text { acquisition) }\end{array}$ & 2,060 & 3,413 & 4,089 & 4,089 \\
\hline Net profit & 1,848 & 3,261 & 3,434 & 3,857 \\
\hline Total & 15,581 & 27,703 & 29,568 & 32,786 \\
\hline
\end{tabular}


Table B-2. Itemized Cost and Price Components for Residential PV-Plus-Storage Systems: SmallBattery Case vs. Large-Battery Case

\begin{tabular}{|c|c|c|c|c|c|}
\hline \multirow[b]{2}{*}{$\begin{array}{l}\text { Cost and Price } \\
\text { Components }\end{array}$} & \multirow[b]{2}{*}{$\begin{array}{c}\text { PV Only } \\
5.6 \mathrm{~kW} \\
(\$)\end{array}$} & \multicolumn{2}{|c|}{ Small-Battery Case } & \multicolumn{2}{|c|}{ Large-Battery Case } \\
\hline & & $\begin{array}{c}P V(5.6 \mathrm{~kW}) \\
+ \\
\text { Storage } \\
\text { DC-coupled } \\
3 \mathrm{~kW}, 6 \\
\mathrm{kWh} \\
(\$) \\
\end{array}$ & $\begin{array}{c}P V(5.6 \mathrm{~kW}) \\
+ \\
\text { Storage } \\
\text { AC-coupled } \\
3 \mathrm{~kW}, 6 \\
\mathrm{kWh} \\
(\$)\end{array}$ & $\begin{array}{c}P V(5.6 \mathrm{~kW}) \\
+ \\
\text { Storage } \\
D C \text {-coupled } \\
5 \mathrm{~kW}, 20 \\
\mathrm{kWh} \\
(\$)\end{array}$ & $\begin{array}{c}P V(5.6 \mathrm{~kW}) \\
+ \\
\text { Storage } \\
\text { AC-coupled } \\
5 \mathrm{~kW}, 20 \\
\mathrm{kWh} \\
(\$) \\
\end{array}$ \\
\hline PV modules & 3,584 & 3,584 & 3,584 & 3,584 & 3,584 \\
\hline Lithium-ion battery & - & 3,000 & 3,000 & 10,000 & 10,000 \\
\hline PV inverter (grid-tied) & 857 & - & 857 & - & 857 \\
\hline $\begin{array}{l}\text { Battery inverter (bi- } \\
\text { directional) }\end{array}$ & - & 3,596 & 3,596 & 4,795 & 4,795 \\
\hline Structural BOS & 651 & 651 & 651 & 651 & 651 \\
\hline Electrical BOS & 1,072 & 2,731 & 2,413 & 5,463 & 4,826 \\
\hline Supply-chain costs & 966 & 678 & 705 & 1,225 & 1,236 \\
\hline Sales tax & 415 & 914 & 950 & 1,651 & 1,665 \\
\hline Install labor (burdened) & 1,731 & 2,773 & 3,188 & 5,547 & 6,375 \\
\hline $\begin{array}{l}\text { Permitting, inspection, } \\
\text { interconnection }\end{array}$ & 549 & 1,253 & 1,253 & 1,253 & 1,253 \\
\hline Overhead (general \& admin.) & 1,848 & 1,848 & 1,848 & 1,848 & 1,848 \\
\hline $\begin{array}{l}\text { Sales \& marketing (customer } \\
\text { acquisition) }\end{array}$ & 2,060 & 3,413 & 4,089 & 3,413 & 4,089 \\
\hline Net profit & 1,848 & 3,261 & 3,434 & 5,808 & 5,991 \\
\hline Total & 15,581 & 27,703 & 29,568 & 45,237 & 47,171 \\
\hline
\end{tabular}

